\title{
DEVELOPING A SOURCE WATER PROTECTION PLAN FOR BORON IN THE SAN LUIS OBISPO COUNTY WATER SUPPLY
}

\author{
A Thesis \\ Presented to \\ the Faculty of California Polytechnic State University \\ San Luis Obispo
}

\begin{abstract}
In Partial Fulfillment
of the Requirements for the Degree

Master of Science in Agriculture, with a Specialization in Soil Science
\end{abstract}

by

Jenny Macartney

March 2010 
(C) 2010

Jenny Jean Macartney

ALL RIGHTS RESERVED 


\section{COMMITTEE MEMBERSHIP}

TITLE:

AUTHOR:

DATE SUBMITTED:
Developing a Source Water Protection Plan for Boron in the San Luis Obispo County Water Supply

Jenny Macartney

March 2010

COMMITTEE CHAIR: Brent G. Hallock

COMMITTEE MEMBER: William Preston

COMMITTEE MEMBER: Terry Smith 


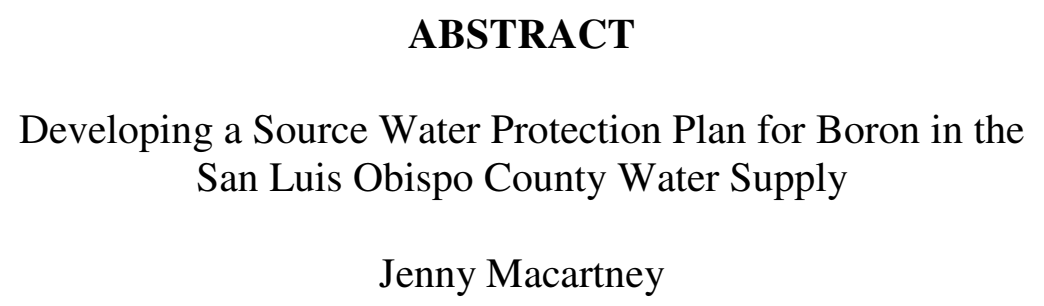

The goal of this project is to design a feasible way to develop a protection plan for boron in the surface waters and groundwater of San Luis Obispo County. Boron is a micronutrient needed by all plants and animals but the threshold for toxicity in plants is narrow. As the need for water increases and the production of wastewater and irrigation water infiltrates the soil and waters of the County, an understanding of background soil and water concentrations, as well as anthropogenically produced sources of boron must be quantified and mapped so that intelligent planning decisions can be made.

Many parties have interests at stake in understanding the nature of the threat posed by high levels of boron in soil and water. Water quality, as a resource, is essential for human health and a viable economy, especially if agriculture is a major economic resource. Many local, state, and federal agencies work in partnership to study, regulate, and implement change to the best management practices that protect and ensure water quality. This project will help evaluate the potential threat of elevated concentrations of boron in the waters of San Luis Obispo County and provide a usable resource that interested parties can reference with regard to this threat. 


\section{TABLE OF CONTENTS}

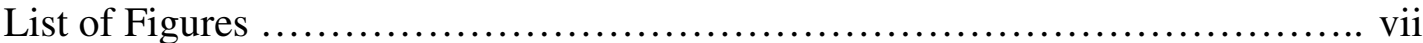

List of Tables ............................................................... vii

Section 1: Introduction....................................................... 1

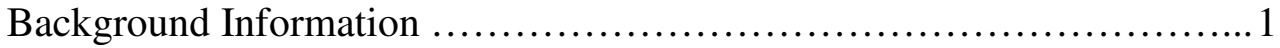

Overall Problem...................................................... 2

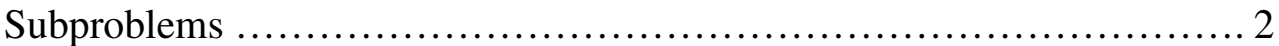

Statement of Subproblem to be Investigated ........................... 3

Importance of the Project ........................................... 3

General Approach …............................................... 3

Section 2: Literature Review ............................................... 5

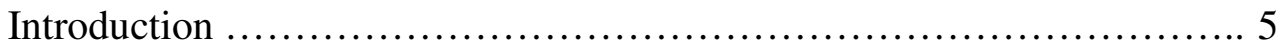

Source Water Protection Plan ........................................ 5

Boron ................................................................. 7

The San Luis Obispo County Water Supply ......................... 12

Section 3: List of Key Factors and Variables ................................. 13

Section 4: Designing a Source Water Protection Plan .............................15

San Luis Obispo County Description ................................ 15

Partnership ..................................................... 17

Groundwater ..................................................... 20

Salinas Valley, Paso Robles Area Subbasin ....................... 23

Cholame Valley ............................................... 24

Los Osos Valley ...............................................25

San Luis Obispo Valley ...................................... 27

Santa Maria Valley ............................................. 28

Cuyama Valley ........................................... 31

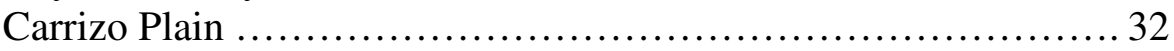

San Carpoforo Valley ......................................... 34

San Simeon Valley ............................................ 34

Santa Rosa Valley ............................................... 35

Villa Valley ........................................................ 36

Cayucos Valley .............................................. 37

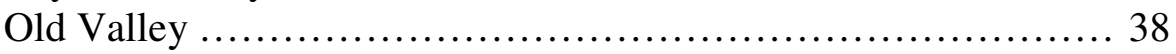

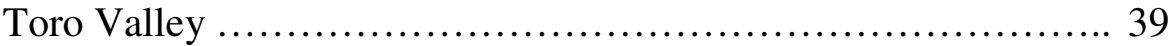

Morro Valley .................................................... 39

Chorro Valley ............................................... 41

Rinconada Valley ......................................... 41

Pozo Valley .................................................... 42

Huasna Valley .................................................. 42

Rafael Valley ................................................ 43

Big Spring ................................................... 43

Surface Water .................................................... 46

Nacimiento ................................................ 46

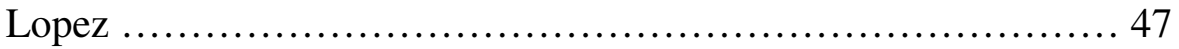

Terminal .................................................. 48 
Salinas ................................................... 48

Chorro ........................................................ 49

Whale Rock .................................................49

State Water Project ........................................... 51

Water Imports from the City of Santa Maria .......................... 55

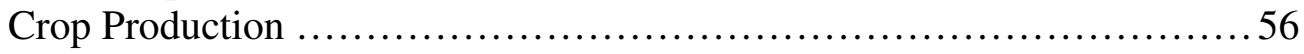

Identifying Anthropogenic Sources of Boron ......................... 61

Water Quality Data ................................................. 62

Management Strategies .........................................6 63

Conclusion ...................................................... 65

Section 4: References .................................................66

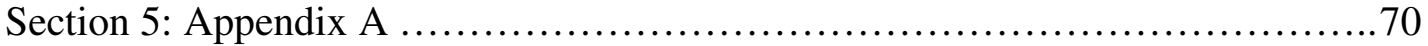

Section 6: Appendix B ............................................... 72 


\section{LIST OF FIGURES}

Figure 4.1 San Luis Obispo County Geographical Location $\ldots \ldots \ldots \ldots \ldots \ldots \ldots \ldots \ldots$

Figure 4.2 Groundwater Basin map ........................................ 22

Figure 4.3 Lake Nacimiento Aerial Photo .................................. 46

Figure 4.4 Lopez Lake Aerial Photo .........................................47

Figure 4.5 Santa Margarita (Salinas) Reservoir Aerial Photo ..................... 48

Figure 4.6 Whale Rock Aerial Photo ........................................... 49

Figure 4.7 San Luis Obispo State Water Project (SWP)Map ..................... 52

Figure 4.8 Water Quality Monitoring Sites, SWP ............................ 53

Figure 4.7 Nipomo .................................................... 55

Figure 4.8 Top Twenty Value Crops .......................................... 57

Figure 4.9 Increasing Value of Crops Over Ten Years ............................ 58

Figure 4.10 Boron Toxicity in Citrus ........................................ 59 


\section{LIST OF TABLES}

Table 4.1 Tasks Performed By Agency Relating To Source Water Protection ...... 18

Table 4.2 Groundwater Quality Objectives .................................. 45

Table 4.3 Reservoir Data Table ............................................ 50

Table 4.4 Surface Water Quality Objectives ................................ 51

Table 4.5Water Quality Grab Sample (partial data set) .........................54

Table 4.6 Top Ten Value Crops Correlated With Boron Toxicity Data .............60

Table 4.7 Suitability of Water for Irrigation .................................6 61

Table 4.8 Water Quality Data Archives ....................................6 63 


\section{$\underline{\text { INTRODUCTION }}$}

\section{BACKGROUND INFORMATION}

Source water protection plans are used to develop a program that will prevent the pollution of water sources. A source water protection plan will commonly delineate the source water protection area(s), identify the sources of contamination that may affect the source water protection area(s), develop management measures for these sources, and propose long term planning (Ainsworth et al., 1996).

Elevated concentrations of boron in the water supply will be the basis for the study on the need for a source water protection plan for Boron. Boron is one of seven essential micronutrients required for plant growth (Gupta, 1993). Boron is essential for the following plant growth processes: cell wall development (Reid, 2007), new cell development in meristematic tissue, proper pollination and fruit or seed set, the synthesis of amino acids and proteins, the regulation of carbohydrate metabolism, and other essential plant processes. Although essential for these processes, the range between boron deficiency and toxicity in plants is narrow (Tisdale et al., 1993).

Boron occurs naturally and from anthropogenic sources. Boron is derived from the weathering of boron containing rocks, the infiltration of meteoric salts, and from mixing with adjacent groundwaters (United States Geologic Survey, 1998). Boron may also be introduced to groundwater basins or surface water bodies from geothermal wastewater, thermal springs and seawater (Koc, 2007). In arid and semiarid environments in California, boron can accumulate where draining and/or leaching is restricted (Peryea and Bingham, 1984). Anthropogenic sources of boron include sewage 
effluent, detergent, fertilizer, insecticides (Gupta, 1993), herbicides and residual wastes from burning plant based products such as wood, coal or oil (Koc, 2007).

The San Luis Obispo County water supply includes groundwater and surface water. Some of the 22 groundwater basins within the County have high levels of boron (Fugro West and Cleath and Associates, 2002). As boron levels rise, plant toxicity may become more apparent.

\section{Overall Problem}

Elevated levels of boron that may pose toxicity threats to humans and/or plants may exist in some aquifers within San Luis Obispo County. The use of water containing high levels of boron for domestic water supply and agricultural use may introduce excessive amounts of boron into the drinking water and the soils of cropland irrigated for agricultural use.

\section{SUBPROBLEMS}

Elevated levels of boron in the water supply may cause accidental contamination between aquifers. Data on the elevated levels of boron may be used for crop and water quality pairing. Fertilizer application rates of boron may be misapplied if boron is occurring in the water supply. 


\section{STATEMENT OF SUbPROBLEM TO BE INVESTIGATED}

A source water protection plan for boron in the San Luis Obispo County water supply will need to be developed to prevent the contamination of groundwater aquifers that do not currently exhibit trends of high boron concentration in the groundwater.

\section{Importance of the Project}

A source water protection plan for boron is an essential tool for the community and for water resource agencies to prevent boron pollution in the water supply. Water is a limited resource essential for human life. Protecting the water supply from boron contamination will help preserve the County's existing water resources.

\section{General APProach}

The first step to developing a guide for completing a source water protection plan will be to identify those parties that would make up a source protection team, including members of local and statewide agencies involved in water quality and water supply interests in San Luis Obispo County. The goal of establishing this team is to encourage a positive, coordinated approach towards protecting a scarce resource that crosses political and regulatory boundaries.

Research will consist of a document survey of existing groundwater and surface water data, including the depth of well, depth to water, boron concentration, well or surface water body location, reporting laboratory, data of data collection, and other parameters as appropriate. The data collected will be analyzed and mapped in 
conjunction with local geologic units and included in this project. This project will provide information and methods to protect water resources from boron contamination. 


\section{LITERATURE REVIEW}

\section{INTRODUCTION}

The overall problem to be evaluated in the thesis titled "Source Water Protection Plan for Boron in the San Luis Obispo County Water Supply" is as follows: elevated levels of boron may pose toxicity threats to humans and/or plants in some groundwater and surface water in San Luis Obispo County. This literature review broadly examines source water protection plans, boron, and the San Luis Obispo County water supply.

\section{Source Water Protection Plan}

Source water protection plans are used to develop a program that will prevent the pollution of water sources. The type of water source identified in the plan is specific to the contaminant and contamination pathway of concern.

Many models exist for developing source water protection plans. One model for a source water protection program identifies four basic steps to prevent contamination: 1) delineate source water protection area(s); 2) identify sources of contamination that may affect source water protection area(s); 3) develop management measures for these sources; and 4) long term planning (Ainsworth et al., 1996). Another method to developing a source water protection plan, prepared by the New Jersey Plaistow Source Water Protection Committee and the Northeast Rural Water Association (2001) includes the following structured approach for managing potential sources of contamination and threatening activities within an identified source protection area: 1) identify source protection area; 2) identify potential contaminant sources; 3) assess contaminant criteria 
and rank the threat to the water source; 4) develop management measures to reduce the potential risk of contamination to water sources; and 5) develop a contingency plan. California's Department of Health Services has developed a similar format, known as the Drinking Water Source Assessment and Protection Program (DWSAP) (California Department of Health Services, 2000). The components of the DWSAP include: delineating the area around drinking water sources that contaminants might move through to reach the water supply; an inventory of possible contaminating activities; and determining the vulnerability of the water to each contaminating activity (California Department of Health Services, 2000).

The cost of failing to implement a source protection plan may include the costs of treatment and/or remediation, finding and establishing new supplies or providing bottled water, paying for consulting services and staff time, litigation, public information campaigns, and the costs associated with meeting minimum water quality requirements (Ainsworth et al., 1996).

Californians are more often recognizing the need for more extensive water quality monitoring and recognizing that it is essential that the various agencies and parties with access to water quality data coordinate and collaborate in the sharing of that data. The Groundwater Quality Monitoring Act of 2001, required by the state legislature, is evidence of these concerns. The result of this act has been the creation of the Groundwater Ambient Monitoring Assessment Program by the California State Water Board to improve groundwater monitoring and assessment and to provide this information to the public (www.swrcb.ca.gov/gama/). 
There are local, statewide, and national campaigns taking place to recognize and implement plans to treat water or design ways to prevent water pollution. In California some basins are already required to establish limitations to impairments in various water bodies. The U.S. Environmental Protection Agency Clean Water Act (CWA) State Revolving Loan Fund (SRF) is one example of programs available for states to restore and protect water resources. This fund is available for water quality and environmental improvement projects. In 2004, the U.S. Environmental Protection Agency, Region 9 (which includes the state of California) funded nine Water Quality Cooperative Agreements Awards. At least two of these (the Framework for Salinity Water Quality Standards (WQS) Evaluation in the San Joaquin River, Central Valley Regional Water Quality Control Board (CA), and the Muddy River TMDL - Boron, Iron, Temperature, Phosphorus, Nevada Department of Environmental Protection) funded proposals relating to boron with regards to water quality standards

(www.epa.gov/region09/water.grants/index.html).

More and more communities, particularly those in semi-arid and arid regions, are focusing water planning projects on defining clear water quality objectives and identifying ways to deal with water quality problems.

\section{BORON}

Boron is one of the seven essential micronutrients, or trace elements, required for normal growth by most plants. Boron is the only non-metal plant micronutrient (Gupta 1993). Boron is the only element among the essential mineral nutrients that is present in the soil solution as a non-ionized molecule over the $\mathrm{pH}$ range suitable for plant growth (Gupta 1993). 
Boron exists in four major forms in the soil: in rocks and minerals; on clay surfaces and iron and aluminum oxides; combined with organic matter; and as boric acid and boron in the soil solution (Tisdale et al, 1993). Factors that influence boron adsorption and desorption from soil constituents are: 1) boron concentration in the soil solution; 2) $\mathrm{pH}$; 3 ) type of exchangeable ions; 4) ionic composition of the soil solution; and 5) wetting and drying cycles (Yerimiyahu et al., 2001).

Boron occurs naturally and from anthropogenic sources. Boron is naturally derived from leaching rocks, the infiltration of meteoric salts, and from mixing with adjacent groundwaters (USGS 1998). High concentrations of naturally occurring boron are primarily found in arid and semiarid environments where drainage and/or leaching are restricted (Peryea and Bingham 1984). In California, soluble boron, along with selenium, accumulates naturally from the weathering of sedimentary sandstones and shale from California's Coastal Ranges (Banuelos et al., 1993). It is estimated that 360,000 metric tons of boron are released globally from volcanic eruptions, weathering and geothermal processes (U.S. Environmental Protection Agency Office of Water Health and Ecological Criteria Division, 2008).

Anthropogenic sources of boron include sewage effluents, detergents, fertilizers, and insecticides (Gupta 1993). Production of boron minerals in the United States is centered in Southern California (USGS Mineral Commodity Summaries 2003). The sources of these reserves are primarily sediments and their contained brines (USGS Mineral Commodity Summaries 2003).

Boron is essential to plant growth. The uptake of boron by plants is controlled by the boron level in the soil solution rather than the boron content of the soil (Yerimiyahu 
et al., 2001). Boron is essential for the following plant growth processes: new cell development in meristematic tissue; proper pollination and fruit or seed set; translocation of sugars, starches, nitrogen and phosphorus; the synthesis of amino acids and proteins; nodule formation in legumes; and the regulation of carbohydrate metabolism (Tisdale et al., 1993).

Although it is essential for these growth processes, the range between boron deficiency and toxicity in plants is very narrow (Tisdale et al., 1993). Burned leaf margins, crusty deposits on leaves and dead areas on older leaves are a few of the symptoms of boron toxicity in plants (Johnson 2001). One method of representing threshold tolerances for plants was established in 1985 by Keren and Bingham. The ranges are described as sensitive $\left(0.078-0.093 \mathrm{~mol} \mathrm{~B} / \mathrm{m}^{3}\right)$, semi-tolerant $(0.093-0.37 \mathrm{~mol}$ $\left.\mathrm{B} / \mathrm{m}^{3}\right)$, and tolerant crops $\left(0.37-1.39 \mathrm{~mol} \mathrm{~B} / \mathrm{m}^{3}\right)$ (Banuelos et al., 1993). Some plants that are recognized for having a higher tolerance for boron are more tolerant due to the presence of a gene or genes that code for how boron moves into the plant's roots, thereby restricting the transfer of boron to shoots (Reid 2007).

Several methods are being studied to remove high levels of boron from the soil and soil solution. One method of reducing high boron concentration in soil to non-toxic levels is by leaching the soil solution with low-boron water sprinkled or ponded on the soil surface. The water dissolves the boron adsorbed by the soil and then drains out of the plant root zone (Peryea and Bingham 1984). This method removes boron more slowly than leaching for salinity, therefore boron is still found in excessive amounts in some reclaimed soils (Banuelos et al., 1993). The rationale for the ineffectiveness of leaching as a method for boron extraction for soils is that boron can be electrically 
attracted to soil particles. As some boron is leached in solution, more boron may become available as boron rich minerals broken down by adding water (Koc 2007, p. 379). As Banuelos, et al. (1993) point out, leaching boron does not address the mobility of the soluble forms of boron to groundwater and the degree of contamination this may cause.

A second method being evaluated is bioremediation of the soil. Different plant species grown in soil containing high concentrations of boron are being tested to see whether vegetation management can be used to lower toxic levels of boron and selenium in soil (Banuelos, et al., 1993).

Desalination systems are also being tested to remove boron from water. Brackish water has been tested using ion exchange resins, reverse osmosis (RO), and a combination thereof (Glueckstern and Priel, 2006). This technology $\mathrm{pH}$ dependent and has been evaluated with many parameters in mind to rate the removal of boron as a part of a technological and economic analysis. Parameters that are taken into account include: "raw water salts composition, especially the boron content, the required boron concentration in the product and all the economical parameters affecting the investment and operating costs of the ion exchanging and the RO systems designed to reduce the boron to the required concentration" (Glueckstern and Priel, 2007).

Studies have also been conducted to develop possible means of extracting boron from wastewater due to the fact that boron is also introduced to water bodies and the soil system through effluent discharge. Some methods currently being researched to treat wastewater are: 1) coprecipitation using metal hydroxide; 2) evaporation crystallization; 3) solvent extraction; 4) ion exchange; 5) membrane filters and 6) hydrothermal treatment (Itakura, et al., 2005). Each of these methods are being 
researched for feasibility. One of the most promising of these methods may be hydrothermal treatment, described as very similar to the formation of borax in nature (Itakura, et al., 2005). Results of this technique have shown that more than $99 \%$ of boron dissolved in wastewater can be recovered and reused as raw mineral in borax production by regulating the amount of $\mathrm{H}_{3} \mathrm{PO}_{4}$ and $\mathrm{Ca}(\mathrm{OH})_{2}$ added to wastewater, the treatment time, and the treatment temperature (Itakura, et al., 2005).

Boron is considered an essential trace element for humans but that has not yet been proven (U.S. Environmental Protection Agency Office of Water Health and Ecological Criteria Division, 2008). Boron intake for men averages at $1.17 \mathrm{mg} / \mathrm{day}$ and for women, $0.96 \mathrm{mg} /$ day (Rainey et al., 1999). The top boron contributors to the human diet are coffee and milk (Rainey et al., 1999). The United States Environmental Protection Agency Reports on Boron intake and toxicity in the publication Health Effects Support Documentation for Boron. This report states that boron is absorbed through the gastrointestinal tract, dermal abrasions, and through inhalation. Numerous studies are evaluated in the report where boron exposure varied in terms of length and concentration of exposure. Some of symptoms associated with higher than average exposures included indigestion, dermatitis, and anorexia. Increased exposure or poisonings is connected to seizures in infants exposed to a honey-borax treatment, vomiting, diarrhea, abdominal pain, lethargy, lightheadedness, rash, and headaches. The E. P.A. Health Reference Level for boron is $1.4 \mathrm{mg} / \mathrm{L}$. (U.S. Environmental Protection Agency Office of Water Health and Ecological Criteria Division, 2008). Rowe (1999) reports that boron may reduce osteoporosis in older women and may have negative effects on the male reproductive system. In 2006 the journal Cancer, Causes and Control published a paper 
that concluded that reduced risk of prostate cancer incidence and mortality is correlated with increased groundwater boron concentrations in Texas (Barranco, et al., 2007).

\section{The San Luis Obispo County Water Supply}

The San Luis Obispo County Water Supply includes groundwater and surface water. The larger portion of water consumption comes from groundwater (San Luis Obispo County Master Plan 2001). Some of the twenty-two groundwater basins within the County have high levels of boron (Fugro West and Cleath and Associates 2002). In addition, consolidated sedimentary formations underlying some of the basins are characterized by elevated boron concentrations (Fugro West and Cleath and Associates 2002). 


\section{List of key factors and variables}

Overall problem: Elevated levels of boron that may pose toxicity threats to humans and/or plants may exist in some aquifers within San Luis Obispo County. The use of water with elevated levels of boron for domestic water supply and agricultural use may introduce excessive amounts of boron into the drinking water and onto irrigated land.

Sub-problems: $\quad$ a. Reduce accidental contamination between aquifers

b. Increase efficiency of crop and water quality pairing

c. Decrease application of fertilizers with boron

d. Identify number of wells within the County

e. Identify geologic history

f. Identify county water management plan

g. Identify present groundwater and surface water sources for the County water supply

Dependent Key Factor: $\quad$ Water demand

Dependent variables: $\quad$ Population

Water supply sources

Types of water use

Volume water consumed

Dependent Key Factor: Water source

Dependent variables: Quality

Volume

Population/location served

Availability of alternative sources

Independent Key Factor: Groundwater mapping

Independent variables: Length of time for recharge

Type of aquifer

Extent of aquifer

Volume

Water Quality

Water table fluctuation

Dependent Key Factor: Boron in groundwater

Dependent variables: Levels consumed/health effects

Crop sensitivity

Health effects

Extent in groundwater

Location of groundwater system

Non-industrial and industrial sources of pollution

Fertilizer content

Crop sensitivity 
Independent Key Factor: Publi policy

Independent variables: Current regulation

Outreach tools

Implementation of EPA health advisory on boron

Dependent Key Factor: Water quality

Dependent variables: Sample size

Sources of information

Reporting to committee

Independent Key Factor: Groundwater wells

Independent variable: Type

Location

Quantity

Depth

Independent Key Factor: Water sampling

Independent variables: Type

Frequency

Laboratory used

Qualities studied 


\section{Designing the Protection Plan}

The overall problem to be evaluated in the thesis titled "Designing a Source Water Protection Plan for Boron in the San Luis Obispo County Water Supply" is as follows: elevated levels of boron may pose toxicity threats to plants that are irrigated using groundwater and surface water in San Luis Obispo County. This is an account of how a source water protection plan for boron can be developed. The design of this plan includes a general description of San Luis Obispo County, a cumulative list of partnership entities that have an in interest in the water quality of San Luis Obispo surface waters and groundwater, a discussion on the lead agency role within the partnership, an identification and overview of the twenty two groundwater basins within the county, an identification and overview of the four surface water bodies used for public water supply, review of water supplied by sources out of the county, current crop value data and toxicity thresholds in agriculture, methods for identifying anthropogenic sources of boron, and methods for collecting water quality data that presently exists at various regulatory agencies. At the conclusion of this account, the participating entities and any interested parties will have a comprehensive water quality study of boron concentrations and trends to base their management strategies.

\section{San Luis Obispo County Description}

San Luis Obispo County has a population of over 200,000 residents, experiencing a population growth rate of approximately $4 \%$ (http://quickfacts.census.gov/qfd/states/06/06079.html). In addition to its resident population, the County has a fluctuating tourist population attracted to the area's 
recreational opportunities, such as the coastal towns and beaches, state and county parks, wineries, antique stores, William Randolph Hearst's La Cuesta Encantada (Hearst Castle), Madonna Inn, California Polytechnic University in San Luis Obispo, and other attractions.

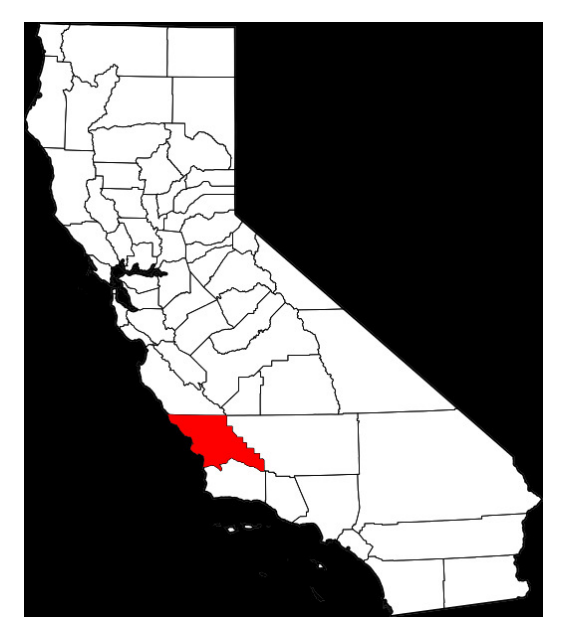

Figure 4.1 San Luis Obispo Geographical Location (Highlighted)

http://commons.wikimedia.org/wiki/Image:Map_of_California_highlighting_San_Luis_Obispo_County.svg

San Luis Obispo County covers 3304.32 square miles and is considered one of three counties in California known as the Central Coast of California (Krieger, p.11, 1990 and http://quickfacts.census.gov/qfd/states/06/06079.html).

San Luis Obispo County's climate is generally described as a Mediterranean type climate, with arid or semi arid conditions. 


\section{PARTNership}

The first step to developing the source water protection plan is to organize a source protection team, including members that represent the following entities with an interest in groundwater quality: California Department of Water Resources, California Regional Water Quality Control Board (Central Coast Region), Resource Conservation Districts, San Luis Obispo County Department of Agriculture / Weights and Measures, San Luis Obispo County Environmental Health Services, San Luis Obispo County Geologist, San Luis Obispo County Planning Department, San Luis Obispo County Public Works, California Department of Public Health (Drinking Water Programs, District 6), U.S. Department of Agriculture (Natural Resources Conservation Service), U.S. Geological Survey, U.S. Environmental Protection Agency, University of California Cooperative Extension, the Bureau of Land Management, and any other representatives integral to water management in San Luis Obispo County. The goal of establishing this team is to encourage a positive, coordinated approach towards protecting a scarce resource that crosses political and regulatory boundaries. Without careful coordination, research may be unnecessarily duplicated or lost due to the sensitive nature of materials related to water supply and water management. The partnership entities will be coordinated to create a usable reference and planning tool to guide best management practices in agriculture, land use, water supply and planning. 


\section{Table 4.1 Tasks of Agencies}

\begin{tabular}{|c|c|}
\hline Agency & Tasks performed by this agency that pertain to source water protection \\
\hline $\begin{array}{l}\text { California Department of } \\
\text { Water Resources (DWR) }\end{array}$ & $\begin{array}{l}\text { State Water Project Analysis Office: Ensures the delivery of water to } 37 \\
\text { million Californians receiving water from the State Water Project (SWP). } \\
\text { (http://www.swpao.water.ca.gov/index.cfm). } \\
\text { Operations and Maintenance Division: responsible for monitoring the } \\
\text { chemical, physical and biological water quality parameters of the state water } \\
\text { project (http://wwwomwq.water.ca.gov/). }\end{array}$ \\
\hline $\begin{array}{l}\text { California Regional Water } \\
\text { Quality Control Board, } \\
\text { Central Coast Region }\end{array}$ & $\begin{array}{l}\text { Responsible for the Central Coast Ambient Water Monitoring Program. } \\
\text { Enforcement of point sources of pollution; and other programs intended to } \\
\text { achieve their three primary operational goals: healthy aquatic habitats, proper } \\
\text { land management and clean groundwater. }\end{array}$ \\
\hline $\begin{array}{l}\text { Resource Conservation } \\
\text { Districts }\end{array}$ & $\begin{array}{l}\text { Resource conservation districts (RCD) are independent state agencies } \\
\text { organized by local residents under state law. Roles of the RCD include soil } \\
\text { and water conservation work. (http://www.coastalrcd.org/frameset.html) }\end{array}$ \\
\hline $\begin{array}{l}\text { San Luis Obispo County } \\
\text { Department of } \\
\text { Agriculture / Weights and } \\
\text { Measures }\end{array}$ & $\begin{array}{l}\text { The mission statement of the Agricultural Resources Division of the } \\
\text { Agricultural / Weights and Measures is "To protect local agricultural } \\
\text { resources and operations by reporting production and value statistics of the } \\
\text { agricultural industry, providing technical information related to land use } \\
\text { impacts to agriculture, and responding to emergencies and disasters affecting } \\
\text { agriculture and the public" (http://www.slocounty.ca.gov/Page8903.aspx). }\end{array}$ \\
\hline $\begin{array}{l}\text { San Luis Obispo County } \\
\text { Environmental Health } \\
\text { Services }\end{array}$ & $\begin{array}{l}\text { Permitting, regulatory, and inspection body for all public and private wells } \\
\text { constructed and destroyed within San Luis Obispo County and small public } \\
\text { water systems within San Luis Obispo County. Data housed includes small } \\
\text { public water system water quality data, well location, and some land use data. }\end{array}$ \\
\hline $\begin{array}{l}\text { San Luis Obispo County } \\
\text { Geologist }\end{array}$ & Contracted position \\
\hline $\begin{array}{l}\text { San Luis Obispo County } \\
\text { Planning Department, } \\
\text { Environmental - Natural } \\
\text { Resources Management }\end{array}$ & $\begin{array}{l}\text { Issues discretionary permits, some of which require geotechnical and soil data } \\
\text { that may have data that correlates to study areas of concern; department } \\
\text { houses archived geology reports in hard copy: may provide data on presence } \\
\text { of geothermal zones that may be a non-point source of boron contamination, } \\
\text { and other geophysical data (McKenzie). }\end{array}$ \\
\hline $\begin{array}{l}\text { San Luis Obispo County } \\
\text { Public Works }\end{array}$ & $\begin{array}{l}\text { Water Resources Advisory Committee: Purpose is to advise the County Board } \\
\text { of Supervisors concerning all policy decisions relating to the water resources } \\
\text { of the SLO County Flood Control and Water Conservation District. } \\
\text { Water Resources Division: Master planning for water and sewer systems, as } \\
\text { well as flood control facilities; current ongoing projects within the county to } \\
\text { improve and expand water storage, treatment, conservation and delivery; } \\
\text { presents annual reports describing the quality of county provided drinking } \\
\text { water; collects and monitors the county's water resources data by utilization } \\
\text { of stream and rain gauges, well measurements, reservoir data, and other } \\
\text { resources to support water resources planning efforts (SLOCountyWater.org). }\end{array}$ \\
\hline
\end{tabular}




\section{Table 3.1 Tasks of Agencies cont.}

\begin{tabular}{|c|c|}
\hline Agency & Tasks performed by this agency that pertain to source water protection \\
\hline $\begin{array}{l}\text { California Department of } \\
\text { Public Health, Drinking } \\
\text { Water Programs, District } \\
6\end{array}$ & $\begin{array}{l}\text { This state agency regulates public drinking water systems. Programs include } \\
\text { the certification of water treatment and distribution operators, oversight to } \\
\text { water recycling projects; permitting treatment devices, water system security, } \\
\text { support to small drinking water systems, etc. This agency also houses the } \\
\text { GeoTracker database of public water system water quality data. } \\
\text { (http://www.cdph,ca.gov/certlic/drinkingwater/Pages/defalt.aspx) }\end{array}$ \\
\hline $\begin{array}{l}\text { United States Department } \\
\text { of Agriculture (USDA), } \\
\text { Natural Resources } \\
\text { Conservation Service } \\
\text { (NRCS) }\end{array}$ & $\begin{array}{l}\text { Provides assistance to landowners and operators for soil, water, and other } \\
\text { resource conservation efforts (http://www.nrcs.usda.gov/). }\end{array}$ \\
\hline $\begin{array}{l}\text { United States Geological } \\
\text { Survey }\end{array}$ & $\begin{array}{l}\text { Currently coordinating with the State Water Resources Control Board } \\
\text { (SWRCB) to implement the Groundwater Ambient Monitoring Program } \\
\text { (GAMA) at locations throughout the state in response to the Ground-Water } \\
\text { Monitoring Quality Act of } 2001 \text { (http://ca.water.usgs.gov/gama/). Data } \\
\text { housed includes local groundwater quality information. }\end{array}$ \\
\hline $\begin{array}{l}\text { United States } \\
\text { Environmental Protection } \\
\text { Agency }\end{array}$ & $\begin{array}{l}\text { The Legacy Data Center (LDC) and STORET are two data management } \\
\text { systems maintained by the EPA that together, contain water quality data for } \\
\text { the nation's waters back to the early 1900's (http://epa.gov/storet/about.html). } \\
\text { Data is accessed at the STORET website. }\end{array}$ \\
\hline $\begin{array}{l}\text { National Climatic Data } \\
\text { Center (U.S. Department } \\
\text { of Commerce) }\end{array}$ & $\begin{array}{l}\text { National center for climatic information. Over } 35 \text { stations exist in San Luis } \\
\text { Obispo County, some containing records as far back as } 1931 \\
\text { (http://www4.ncdc.noaa.gov/cgi-win/wwcgi.dll?WWDI StnSrch) }\end{array}$ \\
\hline $\begin{array}{l}\text { University of California, } \\
\text { Cooperative Extension, } \\
\text { San Luis Obispo County }\end{array}$ & $\begin{array}{l}\text { Director and staff positions that specialize in public education, as farm } \\
\text { advisors specific to viticulture, horticulture, specialty crops, small fruit crops, } \\
\text { vegetables, and sustainable agriculture. }\end{array}$ \\
\hline $\begin{array}{l}\text { United States Department } \\
\text { of the Interior, Bureau of } \\
\text { Land Management (BLM) }\end{array}$ & $\begin{array}{l}\text { This federal agency's mission statement is to sustain the productivity, health } \\
\text { and diversity of public lands. } \\
\text { (http://www.blm.gov/pgdata/content/ca/en/prog.html). }\end{array}$ \\
\hline
\end{tabular}


The lead agency in the development of a source water protection plan for boron in San Luis Obispo County shall coordinate and assimilate the data from the agencies and various entities contributing geological, geophysical, water quality, soil quality, climatic, agricultural crop yield and values, land use and other pertinent data for the purposes of a protection plan. The lead agency will publish the draft(s) and final documents after all data have been collected and evaluated. The lead agency shall then make available to the contributing agencies all data and findings of the protection plan and host a roundtable on the results of the study.

The lead agency status may best lie within the San Luis Obispo County Flood Control and Water Conservation District. This agency, working in cooperation with the Water Resources Advisory Committee for San Luis Obispo County, created the County's Integrated Regional Water Management Program Plan. The plan is designed to incorporate all of the programs within the county that relate to water supply, water quality, ecosystem preservation and restoration, groundwater monitoring and management, and flood management. Grant proposals are reviewed for funding based on specific criteria related to the above programs (SLOCountyWater.org).

\section{GROUNDWATER}

Groundwater monitoring is currently conducted by several agencies and by private well owners for a variety of inorganic and organic constituents (see table 4.1 for more details). Each groundwater basin contains wells constructed to various depths in various locations. Some water monitoring results are available through public 
information request from the Central Coast Regional Water Quality Control Board, San Luis Obispo County Public Works, San Luis Obispo County Environmental Health, California Department of Health Services, California Department of Water Resources, United States Geological Survey, United States Environmental Protection Agency, and others. Some of the records contained within agency archives include boron. Not all wells sampled will have sampling data for boron.

In those wells where sampling for boron has been conducted, the sampling location shall be correlated with the groundwater basin from which the well draws its water. Older wells will have location information with respect to township, range and section, perhaps with more precise identifying markers such as parcel number or addresses. Private wells installed in the last five to seven years, and all public water wells will have GPS coordinates that provide precise location information. In addition, dominant water type (hardness, chloride level, any impairments) and recharge trends will be correlated and graphed with respect to each basin.

There are twenty two groundwater basins in San Luis Obispo County. Each basin varies in productivity, water quality, hydrogeologic information, groundwater impairments, surface area, etc. 


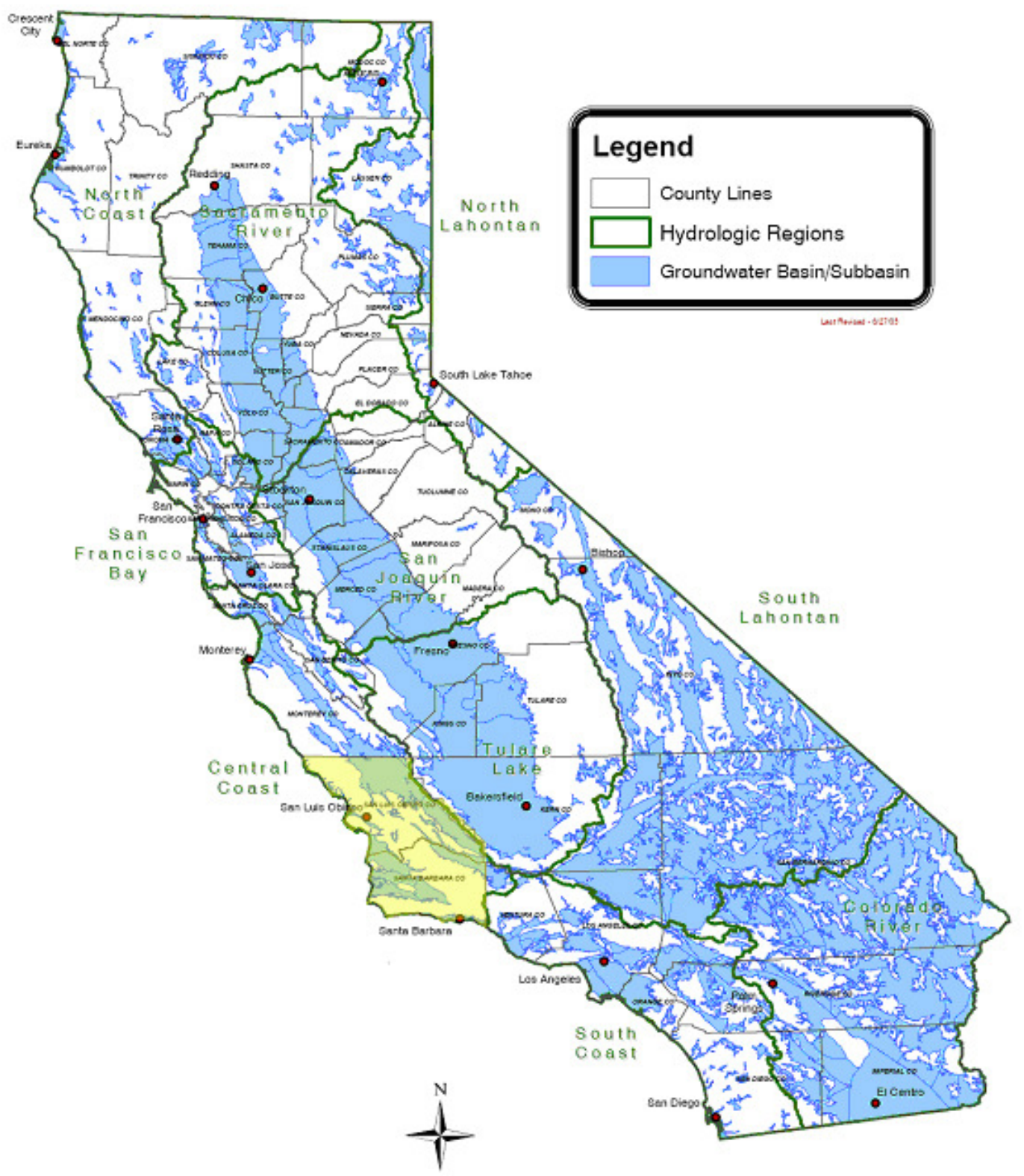

Figure 4.2 DWR Statewide Basin Map, Modified to Highlight

San Luis Obispo County

http://www.dpla2.water.ca.gov/publications/groundwater/bulletin118/maps/correct statewide basin map V3.pdf

A partial reconstruction of basin descriptions from the Department of Water

Resrouces Bulletin 118 is provided here. A full description of each basin can be found at http://www.groundwater.water.ca.gov/bulletin118/basin_desc/basins_s.cfm. 


\section{Salinas Valley, Paso Robles Area Subbasin}

- $\quad$ Surface area 597,000 acres (or 932 square miles)

- Hydrogeologic Information:

- Alluvium: Holocene age alluvium consists of unconsolidated fine to coarse grained sand with pebbles and boulders. This alluvium provides limited amounts of groundwater and reaches 130 feet thick near the Salinas River but is generally less than 30 feet thick in the minor stream valleys. Its high permeability results in a well production capability that often exceeds 1,000gpm. Groundwater in Holocene alluvium is mostly unconfined.

○ Paso Robles Formation: Pleistocene age Paso Robles Formation, which is the most important source of groundwater in the subbasin, is unconsolidated, poorly sorted, and consists of sand, silt, gravel, and clay. This formation reaches a thickness of 2,000 feet and groundwater within it is generally confined

○ Restrictive Structures: The Rinconada fault zone forms a leaky barrier that restricts flow from the Atascadero portion of the subbasin to the main part of the Paso Robles Subbasin. The San Andreas fault restricts subsurface flow.

- Recharge Areas: Natural recharge in the subbasin is derived from infiltration of precipitation, seepage from streams, and return flow from irrigation and other uses. 
○ Groundwater budget: Recharge is estimated at 47,000 af/year. The average subsurface inflow was estimated at 7,500 af and the average subsurface outflow was estimated at 600af. The average streambed percolation was estimated at 41,800 af. The average amount of percolation from irrigation water was determined to be 2,300 af and the average amount of percolation from precipitation was estimated at 42,400 af.

○ Groundwater quality:

- Impairments: Water quality trends indicate an increasing concentration of TDS and chloride in shallow Paso Robles Formation deposits along the Salinas River, and an increasing concentration of chloride in the artesian aquifer in the area northeast of Creston.

\section{Cholame Valley}

- Surface area: 39,800 acres (62 square miles)

- Hydrogeologic information:

- Water Bearing Formations: No specific published information on the water bearing deposits was found. San Joaquin District well completion report files contain logs for 18 wells in the basin. These wells ranged in depth from 100 to 665 feet. They appear to penetrate both alluvial materials and consolidated rocks. Most wells are on the fringe of the basin in the upper canyon areas and are used primarily for domestic water 
supply. Subsurface groundwater inflow and outflow has been reported to occur through the Paso Robles Formation.

- Groundwater level trends: Water level data was found for one well in the basin, which was monitored by the USGS from 1979 to 1994 . Water levels fluctuated from 15 to 60 feet below the landsurface. This well is located in the upper portion of the basin and may not represent conditions lower in the basin. Groundwater flow direction is down valley to the southeast. A groundwater elevation contour map depicting conditions in the fall of 1954 indicates that Cholame Creek was a gaining stream and that groundwater gradient was approximately 33 feet per mile. Observations during a field reconnaissance in September 2001, indicated that at the lower end of the basin, near the intersection of highways 41 and 46, groundwater appears to be discharging to the surface. This is evidenced by lush green growth in the valley and base flow in Cholame Creek.

\section{Los Osos Valley}

- Surface area: 6,990 acres (10.9 square miles)

- Hydrogeologic information

$\circ$ Groundwater is found in alluvium of Holocene age, dune sand and the Paso Robles Formation of Pleistocene age, and the Careaga Sand of Pliocene age.

- Holocene deposits: This alluvium consists of clayey gravel and sand. The thickness of the alluvium ranges from 20 to 65 feet under the Los Osos Creek floodplain. 
- Pleistocene deposits: Dune sand is composed of unconsolidated, fine to medium-grained arkosic sand with thin clay, silt and gravel interlayers. The Paso Robles Formation, which is the main water-producing unit in the basin, typically consists of unconsolidated, interbedded clay and clayey, pebbly sand in discontinuous beds and lenses. It has a thickness of about 300 feet. Clay layers found in the Paso Robles Formation impede the vertical movement of groundwater.

- Pliocene deposits: The Careaga Sand is described as a massive, finegrained, micaceous quartz sandstone, and as unconsolidated deposits of white to yellowish-brown fine to medium grained, marine sand with some silt. This unit has a total thickness up to about 1,000 feet.

- Restrictive structures: The east-trending Los Osos fault traverses the valley and is exposed along southeastern Los Osos Valley. The western end of the Edna fault zone terminates in two parallel, unnamed northtrending faults, which extend into the Los Osos Groundwater Basin west of the point where Los Osos Creek enters the valley. Of those two faults, the esternmost fault is a barrier to groundwater flow.

- Recharge areas: Deep percolation of rainfall accounts for a large portion of recharge to the groundwater basin. Recharge into the alluvium is through underflow and infiltration of surface water in drainage channels. Recharge into the dune sand is through underflow along the lower elevations of the Irish Hills and infiltration of surface water, primarily from Los Osos Creek. Groundwater in the Paso Robles Formation is 
replenished in areas where it is in hydraulic continuity with alluvium, dune sand, and along the basin margins at depths where it intercepts seepage from bedrock.

- Groundwater quality

- Impairments: An increase in chloride concentrations in groundwater along the coast between 1977 and 1986 indicates that sea water has intruded the basin.

\section{San Luis Obispo Valley}

- $\quad$ Surface area: 12,700 acres (19.9 square miles)

- Hydrogeologic Information

- Water bearing formations: Groundwater in the San Luis Obispo Valley Groundwater Basin is found in Pleistocene to Holocene age terrestrial deposits.

○ Holocene deposits: Holocene age alluvium consists of unconsolidated gravel, sand, silt, and clay of fluvial origin that reaches a maximum thickness of about 50 feet. In the portion of the basin that underlies the San Luis Obispo Creek watershed, the alluvium covers the valley floor and is the main source of groundwater. Wells yield from 20 to 300 gpm.

○ Pleistocene deposits: Pleistocene age alluvial terrace deposits as thick as 50 feet and wells completed in these deposits have yields of about 20 gpm. The Paso Robles Formation is composed of poorly sorted, unconsolidated to consolidated conglomerate, sand, silt, gravel, and clay. Well yields are variable, ranging to more than $200 \mathrm{gpm}$. 
- Recharge areas: Recharge of the basin is from infiltration of precipitation on the valley, applied irrigation water, and streamflow.

○ Groundwater quality:

- Impairments Water fromsix wells in the basin has excessive concentration of nitrate and chloride.

\section{Santa Maria Valley}

- Surface area: 184,000 acres (288 square miles)

- Basin boundaries and hydrology: This groundwater basin underlies the Santa Maria Valley in the coastal portion of northern Santa Barbara and southern San Luis Obispo Counties. The basin also underlies Nipomo and Tri-Cities Mesas, Arroyo Grande Plain, and Nipomo, Arroyo Grande and Pismo Creek Valleys. The basin is bounded on the north by the San Luis and Santa Lucia Ranges, on the east by the San Rafael Mountains, on the south by the Solomon Hills and the San Antonio Creek Valley Groundwater Basin, on the southwest by the Casmalia Hills, and on the west by the Pacific Ocean. Several rivers and creeks drain westward to the Pacific Ocean. The Santa Maria Valley is drained by the Sisquoc, Cuyama, and Santa Maria Rivers and Orcutt Creek. Tri-Cities Mesa and Arroyo Grande Plain are drained by Arroyo Grande and Pismo Creeks. Nipomo Valley is drained by Nipomo Creek into the Santa Maria River. Annual precipitation ranges from 13 to 17 inches, with an average of 15 inches.

- Hydrogeologic information:

- Water bearing formations: Groundwater is found in alluvium, dune sands, and the Orcutt, Paso Robles, Pismo, and Careaga Formations. 
Groundwater is unconfined throughout most of the basin except in the coastal portion where it is confined. The average total thickness of the water bearing materials is about 1,000 feet with a maximum thickness of 2,800 .

○ Alluvium and dune deposits: Holocene alluvium consists of unconsolidated lenticular bodies of gravel, sand, silt, and clay. This alluvium reaches a maximum thickness of about 250 feet. Pleistocene and Holocene dune deposits consist of well rounded, fine- to coarse-grained sand. Holocene dune deposits are typically found along a coastal belt and attain a maximum thickness of 100 feet . Pleistocene dune deposits found under Tri-Cities Mesa range to about 60 feet thick and those under Nipomo Mesa range to about 300 feet thick .

- Orcutt Formation: The Pleistocene age Orcutt Formation consists of sand and beds of coarse gravel, with minor amounts of silt and clay restricted to the upper parts of the unit. The Orcutt Formation can reach a maximum thickness of 225 feet, particularly along the axis of the Santa Maria Valley syncline.

○ Paso Robles Formation: The Pliocene-Pleistocene age Paso Robles Formation typically consists of unconsolidated to poorly consolidated coarse to fine-grained gravel, sand, silt, and clay. In this basin, the Paso Robles Formation ranges from about 40 feet near Pismo Creek to 2,000 feet near Orcutt. 
- Careaga Formation: The late Pliocene age Careaga Formation is described as unconsolidated deposits of fine- to medium-grained, marine sand with some silt, and unconsolidated to well consolidated, coarse- to fine-grained sand, gravel, silty sand, silt, and clay. Thickness of this unit ranges from about 150 to 700 feet in the San Luis Obispo County portion of the basin.

- Pismo Formation: The late Pliocene age Squire Member of the Pismo Formation is an important source of groundwater in the basin north of the Santa Maria River fault. The Squire Member consists of coarse- to finegrained sand interbeded with discontinuous layers of silt and clay, and ranges from about 50 to 550 feet thick.

- Restrictive structures: The Santa Maria fault displaces Pliocene units vertically by about 150 feet, and a steepening of the hydraulic gradient near the trace of this fault indicates that this fault is a partial barrier to groundwater flow. The Santa Maria River fault cuts northwestward through the basin in San Luis Obispo County. Water levels at different elevations across some sections of this fault suggest that it is a barrier to groundwater movement in formations below the Pleistocene dune sand deposits.

- Recharge: Natural recharge to the basin comes from seepage losses from the major streams, percolation of rainfall, and subsurface flow. Percolation of flow in Pismo Creek provides recharge for the northern portion of the basin. Percolation of flow in Arroyo Grande Creek, controlled by releases from Lopez Dam, provides recharge for the Tri-Cities Mesa, Arroyo 
Grande Plain, and Arroyo Grande Valley portions of the basin. Percolation of flow in Santa Maria River, controlled in part by releases from Twitchell Dam, provides recharge for the Santa Maria Valley portion of the basin. Both Twitchell and Lopez Dams are operated so as to optimize groundwater recharge for the Santa Maria Groundwater Basin. Incidental recharge includes deep percolation of urban and agricultural return water, treated wastewater return and septic tank effluent. Some subsurface inflow comes from consolidated rocks surrounding the basin and also from San Antonio Creek Valley Groundwater Basin.

\section{Cuyama Valley}

- Surface are: 147,200 (230 square miles)

- The valley is drained by the Cuyama River. Average annual precipitation ranges from 7 inches to 15 inches per year.

- Hydrogeologic information

- Water bearing formations: Groundwater is found in Holocene age alluvium, and older terrestrial deposits. Groundwater in the basin is mainly unconfined, but confined water and perched water are found locally. The specific yield is estimated to range from less than 10 percent in the southwestern part of the basin, to more than 15 percent in the northern and southeastern parts of the basin (DWR 1998).

- Holocene alluvium: In the western part of the basin, the alluvium consists of thick beds of sand and gravel alternating with beds of clay. In the south central part of the basin, alluvium is predominantly sand and silt with 
some beds of gravel and clay. In the eastern part of the basin, alluvium consists of coarse gravel and sand. Except in the western part of the basin, the alluvium is not the principal water-bearing formation. The thickness of the alluvium is inferred to be from 150 to 250 feet.

- Older terrestrial deposits: Pleistocene age terrace deposits found in the valley are relatively thin and mainly above the zone of saturation. Underlying older terrestrial deposits, which include the Pliocene age Cuyama or Morales formation and a fanglomerate, are the main waterbearing units in the basin. These deposits consist of large and extensive bodies of poorly consolidated clay, silt, and gravel.

- Recharge areas: The main source of recharge is seepage from the Cuyama River.

- Groundwater quality:

- Impairments: Because of constant cycling and evaporation of irrigation water in the basin, water quality has been deteriorating. Groundwater near the Caliente Range has high salinity, which has been attributed to seepage out of the basement marine rocks.

\section{Carrizo Plain}

- Surface area: 173,000 (270 square miles)

- Basin boundaries and hydrology: The Carrizo Plain Groundwater Basin underlies a narrow northwest trending valley that lies between the Temblor Range on the east and the Caliente Range and San Juan Hills on the west. The valley has 
internal drainage to Soda Lake. The San Andreas fault zone passes through the valley. Average annual precipitation ranges from 7 to 9 inches.

- Hydrogeologic information

- Groundwater is found in alluvium and the Paso Robles and Morales Formations.

- Alluvium: Upper Pleistocene to Holocene alluvium consists of unconsolidated to loosely consolidated sands, gravels, and silts with a few beds of compacted clays.

○ Paso Robles Formation: The Pleistocene age Paso Robles Formation consists of poorly sorted, mostly loosely consolidated gravels, sands, and silts. The combined thickness of these deposits is more than 3,000 feet in the eastern portion of the basin along the San Andreas fault and decreases toward the west.

○ Morales Formation: The Upper Pliocene Morales Formation consists of sands, gravels, and silts, which generally are more stratified and compacted than in the overlying Paso Robles Formation.

- Recharge areas: Recharge to the basin is largely by percolation of stream flow and infiltration of rainfall to the valley floor.

○ Groundwater quality:

- Characterization: Analyses of groundwater from 79 wells in this basin done during 1957 and 1985 shows TDS content ranging from 161 to $94,750 \mathrm{mg} / \mathrm{L}$. A highly mineralized groundwater zone is found in the lower part of the alluvium and upper part of the Paso 
Robles Formation where they underlie Soda Lake. Water in the deeper zone in the Paso Robles Formation is of higher quality and confined in the vicinity of Soda Lake. Groundwater in the Morales Formation is likely to be brackish.

\section{San Carpoforo Valley}

- $\quad$ Surface area: 200 acres (0.3 square miles)

- Basin boundaries and hydrology: The San Carpoforo Valley Groundwater Basin underlies San Carpoforo Valley in northwestern San Luis Obispo County. The basin is bounded on the west by the Pacific Ocean and on all other sides, by impermeable rocks of the Jurassic to Cretaceous age Franciscan Group. The valley is drained by San Carpoforo Creek. Annual precipitation averages 21 to 25 inches.

- Hydrogeologic information:

- Water bearing formations: Groundwater is found in Holocene and late Pleistocene age alluvium.

- Recharge areas: Recharge to the basin is largely by percolation of stream flow and to a lesser extend from infiltration of precipitation and excess irrigation flow.

\section{San Simeon Valley}

- Surface area: 620 acres (1.0 square miles)

- Basin boundaries and hydrology: The San Simeon Valley Groundwater Basin underlies San Simeon Valley and is bounded by the Pacific Ocean on the west, the Santa Lucia Range on the east, and elsewhere by impermeable Franciscan 
Group rocks. The valley is drained by San Simeon Creek. Precipitation varies across the watershed from 20 inches at the coast to about 26 inches at the eastern end of the valley floor to more than 40 inches at the headwaters of San Simeon Creek.

- Hydrogeologic information:

- Water bearing formations: Groundwater is found in Holocene age alluvial deposits.

- Holocene deposits: Unconsolidated alluvial deposits underlie San Simeon Creek and consist of unconsolidated gravel, sand, clay and silt. The alluvium has a maximum thickness of about 100 feet beneath the center of the valley and more than 120 feet at the coast.

- Recharge areas: Groundwater is unconfined and flows generally westward. Recharge to the basin is largely by percolation of stream flow and, to a lesser extend, from deep infiltration of precipitation and excess irrigation flow.

\section{Santa Rosa Valley}

- Surface area: 4,480 acres (7.0 square miles)

- Basin boundaries and hydrology: The Santa Rosa Valley Groundwater Basin underlies Santa Rosa Valley and is bounded on the west by the Pacific Ocean and on all other sides by impermeable rocks of the Jurassic to Cretaceous age Franciscan Group. The valley is drained by Green Valley, Perry, and Santa Rosa Creeks. Average annual rainfall increases from about 20 inches at the coast to 
about 26 inches at the eastern end of the valley floor to more than 40 inches at the creek headwaters.

- Hydrogeologic information:

- Water bearing formations: Groundwater is found in alluvial deposits with an average specific yield of 17 percent. Groundwater is unconfined and generally flows westward.

- Holocene deposits: Alluvial deposits consist of unconsolidated sand, clay, silt, and gravel of primarily fluvial origin. Commonly, the deposits are about 100 feet thick beneath the center of the valley and more than 120 feet thick at the coast.

- Recharge areas: Recharge to the basin is largely by percolation of stream flow and, to a lesser extent, from infiltration of precipitation and excess irrigation flow.

○ Groundwater quality:

- Impairments: There is evidence that points to the possibility of sweater intrusion. Chloride content increased more than ten times, from $80 \mathrm{mg} / \mathrm{L}$ in 1955 to $933 \mathrm{mg} / \mathrm{L}$ in 1975 . Background chloride concentrations typically ranged from 30 to $270 \mathrm{mg} / \mathrm{L}$.

\section{Villa Valley}

- Surface area: 980 acres (1.5 square miles)

- Basin boundaries and hydrology: The Villa Valley Groundwater Basin is bounded on the south by the Pacific Ocean and on the north, east, and west by 
impermeable rocks of the Jurassic to Cretaceous age Franciscan Group. The basin is drained by Villa Creek, which flows into Estero Bay.

- Hydrogeologic information:

- Water bearing formations: Groundwater is found in Holocene and late Pleistocene age alluvium.

- Alluvium: The alluvium, which consists of sand, gravel and clay, ranges to 130 feet thick.

- Recharge areas: Recharge to the basin is largely by percolation of stream flow and to a lesser extent from infiltration of precipitation and excess irrigation flow.

○ Groundwater quality:

- Impariments: Chloride was found to exceed $100 \mathrm{mg} / \mathrm{L}$ during 1953 to 1955 and 1967 to 1969 , and samples collected in 1974 show chloride in excess of $800 \mathrm{mg} / \mathrm{L}$. It is not known whether or not high levels are caused by sea-water intrusion.

\section{Cayucos Valley}

- $\quad$ Surface area: 530 acres (0.8 square miles)

- Basin boundaries and hydrology: The Cayucos Valley Groundwater Basin is bounded on the south by the Pacific Ocean and on all other sides by impermeable rocks of the Jurassic to Cretaceous age Franciscan Group. The valley is drained to the Pacific Ocean by Cayucos Creek. Precipitation ranges from 16 to 18 inches. 
- Hydrogeologic information:

$\circ$ Water bearing formations: Groundwater is found in Pleistocene and Holocene alluvium and terrace deposits.

- Alluvium: Alluvium consists of unconsolidated sand, clay, silt, and gravel. The deposits are often about 100 feet thick near the center of the valley and more than 120 feet thick at the coast.

- Terrace deposits: Stream-terrace deposits are primarily unconsolidated deposits of marine origin. They are generally less than 10 feet thick.

- Groundwater level trends: Groundwater movement is generally southward.

- Groundwater quality:

- Impairments: Portions of the basin have chloride levels exceeding $100 \mathrm{mg} / \mathrm{L}$, indicating sweater intrusion has occurred.

\section{Old Valley}

- Surface area: 750 acres (1.2 square miles)

- Basin boundaries and hydrology: The Old Valley Groundwater Basin is bounded on the south by the Pacific Ocean and on all other sides by impermeable rocks of the Jurassic to Cretaceous age Franciscan Group. The basin is drained by Cottontail and Old Creeks to the Pacific Ocean. Whale Rock Reservoir is in Old Valley. Precipitation ranges from 16 to 18 inches.

- Hydrogeologic information:

- Water bearing formations: Groundwater is found in alluvium of Holocene and Pleistocene age, which consists of sand, gravel, and clay, and ranges to 135 feet thick. Groundwater is unconfined. 
- Recharge areas: Recharge to the basin is largely by percolation of stream flow and to a lesser extent from infiltration of precipitation and excess irrigation flow.

\section{Toro Valley}

- Surface area: 720 acres (1.1 square miles)

- Basin boundaries and hydrology: The Toro Valley Groundwater Basin underlies Toro Valley in west-central San Luis Obispo County. The basin is bounded on the west by the Pacific Ocean and on all other sides, by impermeable rocks of the Jurassic to Cretaceous age Franciscan Group. The valley is drained by Toro Creek to the Pacific Ocean at Estero Bay.

- Hydrogeologic information:

- Water bearing formations: Groundwater is found in Holocene and late Pleistocene age alluvium.

- Alluvium: The alluvium, which consists of sand, gravel, and clay, ranges to 80 feet thick. Goundwater is largely unconfined.

- Recharge areas: Recharge to the basin is largely by percolation of stream flow and to a lesser extent from infiltration of precipitation and excess irrigation flow.

○ Groundwater quality:

- Impairments: Historical data indicate chloride levels exceeding $100 \mathrm{mg} / \mathrm{L}$.

\section{Morro Valley}

- Surface area: 1,200 acres (1.9 square miles) 
- Basin boundaries and hydrology: The Morro Valley Groundwater Basin underlies Morro Valley in west-central San Luis Obispo County. The basin is bounded on the west by the Pacific Ocean and on all other sides by contact with impermeable rocks of the Jurassic to Cretaceous age Franciscan Group. The valley is drained by Morro Creek to the Pacific Ocean. Precipitation ranges from 15 to 17 inches per year.

- Hydrogeologic information:

Water bearing formations: Groundwater is found in alluvium, dune sand, and terrace deposits. Well logs indicate a thickness of sedimentary rocks of about 60 . Groundwater is unconfined.

- Alluvium: Holocene and Pleistocene age alluvium, which is the main source of groundwater, consists of clays, silts, and gravels.

- Dune sand: Dune sand consists of very fine to medium grained sands with thin interbeds of clay, silt and gravel.

- Terrace deposits: Terrace deposits consist of unconsolidated sand, gravel and clay of fluvial and marine origin with a thickness up to 60 feet.

- Recharge areas: Recharge to the basin is by percolation of stream flow, precipitation, and excess irrigation flow.

- Groundwater quality:

- Impairments: Water from two wells near the coast sampled in 1970 had a chloride content of about $690 \mathrm{mg} / \mathrm{L}$ and $900 \mathrm{mg} / \mathrm{L}$. 


\section{Chorro Valley}

- Surface area: 3,200 acres (5.0 square miles)

- Basin boundaries and hydrology: The Chorro Valley Groundwater Basin underlies Chorro Valley in westcentral San Luis Obispo County. The basin is bounded on the west by the Pacific Ocean and on all other sides by impermeable Franciscan Group and Miocene intrusive rocks. Chorro Creek drains this valley into Morro Bay. Precipitation ranges from 15 to 19 inches.

- Hydrogeologic information:

- Water bearing formations: Groundwater is found in Holocene and late Pleistocene age alluvium, which consists of sand, gravel, and clay. The alluvium reaches a thickness of 70 feet near the mouth of Chorro Creek.

- Recharge areas: Recharge to the basin is by percolation of stream flow, precipitation and excess irrigation flow.

- Groundwater quality:

- Impairments: Chlorides were found to exceed $100 \mathrm{mg} / \mathrm{L}$ during 1953 to 1955 . During a dry period, 1959 through 1960, chloride concentrations reached levels of 2,000 to $2,500 \mathrm{mg} / \mathrm{L}$.

\section{Rinconada Valley}

- Surface area: 2,580 acres (4.0 square miles)

- Basin boundaries and hydrology: Rinconada Valley Groundwater Basin underlies Rinconada Valley in central San Luis Obispo County. This basin is bounded by Miocene age marine rocks and Mesozoic Franciscan Group rocks. The Rinconada Valley Groundwater Basin lies generally along the Nacimiento and Rinconada faults. The valley 
is drained by Rinconada Creek, a tributary to the Salinas River. Precipitation ranges from 20 to 24 inches per year.

- Hydrogeologic information:

- Water bearing formations: The principal water-bearing unit is Quaternary age alluvium.

- Restrictive structures: The Rinconada and Nacimiento faults cross this basin, but it is not known whether or not these faults are groundwater barriers.

\section{Pozo Valley}

- $\quad$ Surface area: 6,840 acres (10.7 square miles)

- Basin boundaries and hydrology: The Pozo Valley Groundwater Basin, which is in central San Luis Obispo County, is bounded on all sides by low permeability rocks of Cretaceous and Miocene age. The basin is drained by Pozo Creek and the Salinas River, both of which flow into Santa Margarita Lake. Precipitation ranges from 19 to 23 inches.

- Hydrogeologic information:

$\circ$ Water bearing formations: Groundwater is found in alluvium of Holocene age.

- Alluvium: The alluvium, which consists of sand, gravel, and clay, is up to 30 feet thick.

- Recharge areas: Recharge to the basin is by percolation of stream flow, precipitation in the valley, and excess irrigation flow.

\section{Huasna Valley}

- $\quad$ Surface area: 4,700 acres (7.3 square miles) 
- Basin boundaries and hydrology: Huasna Valley Groundwater Basin underlies valleys drained by two branches of Huasna Creek in southern San Luis Obispo County. The basin is bounded by Miocene age marine rocks and the valleys are drained by Huasna Creek to Twitchell Reservoir. Precipitation ranges from 16 to 20 inches per year.

- Hydrogeologic information:

- Water bearing formations: The principal water bearing unit is Quaternary age alluvium.

\section{Rafael Valley}

- Surface area: 2,990 acres (4.7 square miles)

Basin boundaries and hydrogeology: Rafael Valley Groundwater Basin underlies Rafael Valley in southeastern San Luis Obispo County. This basin is bounded by Cretaceous and Miocene age marine rocks (Jennings 1958). The valley is drained by Rafael and San Juan Creeks. The basin is generally parallel to, and is crossed by the Chimeneas fault. Precipitation ranges from 8 to 10 inches per year.

- Hydrogeologic information:

- Water bearing formations: Quaternary age alluvium is the principal waterbearing unit in this basin.

- Restrictive structures: The Chimeneas fault crosses the basin, but it is not known whether or not this fault is a groundwater barrier.

\section{Big Spring}

- Surface area: 7,320 acres (11.4 square miles)

- Basin boundaries and hydrology: Big Spring Area Groundwater Basin underlies a valley in southern San Luis Obispo County. The basin is bounded by Miocene age 
marine rocks. The valley is drained by a tributary to San Juan Creek. Precipitation ranges from 8 to 10 inches per year.

- Hydrogeologic information

- Water bearing formations: The main water-bearing unit is Quaternary age alluvium.

A common trend regarding recharge is observable in nearly all of the groundwater basins where recharge data is available. Significant recharge to the basins is supplied by infiltration of precipitation, seepage from streams, and return flow from irrigation and other uses. Of most concern in this source water protection plan is the return flow from irrigation water and other uses. Because water is imported from other areas, such as the water entering the county from the State Water Project, and because water is moved between basins, it is possible for water high in boron to be imported and recharged into basins having initially higher quality water. Of equal concern is the deterioration of recharge water from irrigation. If, on irrigated agricultural lands, herbicides, insecticides, or fertilizers are used that contain boron, that boron can become concentrated in the soils and water underlying the agricultural crop.

Other land use practices that may lead to increased boron concentrations is the discharge of wastewater from industrial or public sources and geothermal areas. This discharge may result in local recharge of poor quality water into the groundwater basin or, when applicable, may result in discharge to surface water bodies, responsible for transporting that lesser quality water to other parts of the basin. 
The County of San Luis Obispo has established an objective for boron concentration in groundwater. Water quality objectives are generally based on the California Code of Regulations (CCR), Title 22 requirements. In the case of boron, no standard exists in CCR, Title 22, so the standard has been established by the Regional Water Quality Control Board.

Table 4.2 Groundwater Quality Objectives, San Luis Obispo County Master Water Plan, 2001 (table modified to include only boron). Water planning area defined more fully in Appendix A.

\begin{tabular}{|c|c|c|}
\hline \multicolumn{3}{|c|}{ Ground Water Quality Objectives } \\
\hline & ing Area & Boron $(\mathrm{mg} / \mathrm{L})$ \\
\hline WPA - 1 & $\begin{array}{c}\text { North Coast } \\
\text { Santa Rosa Creek }\end{array}$ & 0.2 \\
\hline WPA - 3 & $\begin{array}{c}\text { Los Osos/Morro Bay } \\
\text { Chorro }\end{array}$ & 0.2 \\
\hline WPA - 4 & $\begin{array}{c}\text { San Luis Obispo/Avila } \\
\text { San Luis Obispo }\end{array}$ & 0.2 \\
\hline WPA - 5 & $\begin{array}{c}\text { Five Cities } \\
\text { Arroyo Grande }\end{array}$ & 0.2 \\
\hline WPA - 6 & $\begin{array}{c}\text { Nipomo Mesa } \\
\text { Nipomo Sub-basin }\end{array}$ & 0.15 \\
\hline WPA - 7 & $\begin{array}{c}\text { Cuyama } \\
\text { Cuyama Valley }\end{array}$ & 0.4 \\
\hline WPA -8 & $\begin{array}{l}\text { California Valley } \\
\text { Soda Lake }\end{array}$ & $\begin{array}{l}\text { Groundwater } \\
\text { currently } \\
\text { exceeds usable } \\
\text { mineral quality }\end{array}$ \\
\hline WPA - 9a & $\begin{array}{c}\text { Salinas } \\
\text { San Miguel } \\
\text { Paso Robles } \\
\text { Templeton } \\
\text { Atascadero }\end{array}$ & $\begin{array}{l}0.5 \\
2.0 \\
0.3 \\
0.3\end{array}$ \\
\hline$W P A-9 b$ & $\begin{array}{l}\text { Creston } \\
\text { Central }\end{array}$ & 0.3 \\
\hline $\mathrm{WPA}-9 \mathrm{c}$ & $\begin{array}{l}\text { Shandon } \\
\text { Estrella }\end{array}$ & $\begin{array}{c}0.75 \\
2.8 \\
\end{array}$ \\
\hline
\end{tabular}




\section{SurfaCe Water}

The five major reservoirs located within San Luis Obispo County are Nacimiento, Lopez, (including Terminal), Whale Rock, Chorro and Salinas. Surface water bodies are subject to contamination from point and non-point source pollution. Due to the large areas that these reservoirs serve, the potential exists for boron contaminated water to be distributed for use from these sources over large areas of the county.

\section{Nacimiento}

Nacimiento Reservoir is located in northern San Luis Obispo County and is operated by the Monterey County Water Resources Agency. The reservoir construction was completed in 1957, currently capable of storing 377,900 acre feet at maximum capacity. The County of San Luis Obispo has the right to 17,500 acre feet of water each year, supplied to properties around the lake. Plans exist to expand the supplied users to include the City of Paso Robles, Atascadero Mutual Water Company, Templeton Community Services District and the City of San Luis Obispo (Werst, et al, 2005).

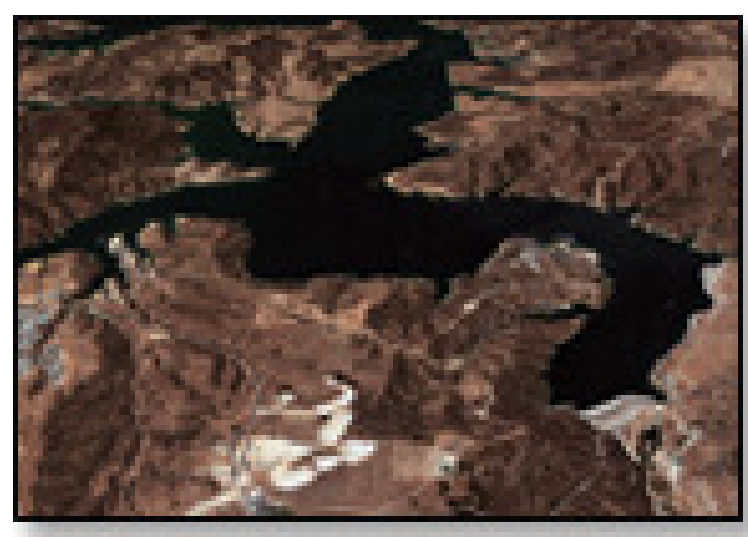

Figure 4.3 Lake Nacimiento Aerial Photo Taken July 2007, Courtesy of San Luis Obispo County Water Resources (SLOCountyWater.org) 
Lopez

Lopez Reservoir is located east of the City of Arroyo Grande in San Luis Obispo County and was constructed between 1967 and 1969 (San Luis Obispo County Flood Control and Water Conservation District 2005). As of the 2005 Lopez Reservoir Urban Water Management Plan Update, the reservoir was serving 53,249 municipal and agricultural users in Oceano, Grover Beach, Pismo Beach, Arroyo Grande and some unincorporated areas, including Avila Beach (San Luis Obispo County Flood Control and Water Conservation District 2005).. The capacity of the reservoir is 49,388 acre feet over an area of about 164,000 acres within the Arroyo Grande Creek drainage area. The safe yield of the reservoir is 8,730 acre feet per year, of which about half is for pipeline users and half is for downstream releases (San Luis Obispo County Flood Control and Water Conservation District 2005). The reservoir is operated by the San Luis Obispo County Flood Control and Water Conservation District (Werst, et al., 2005).

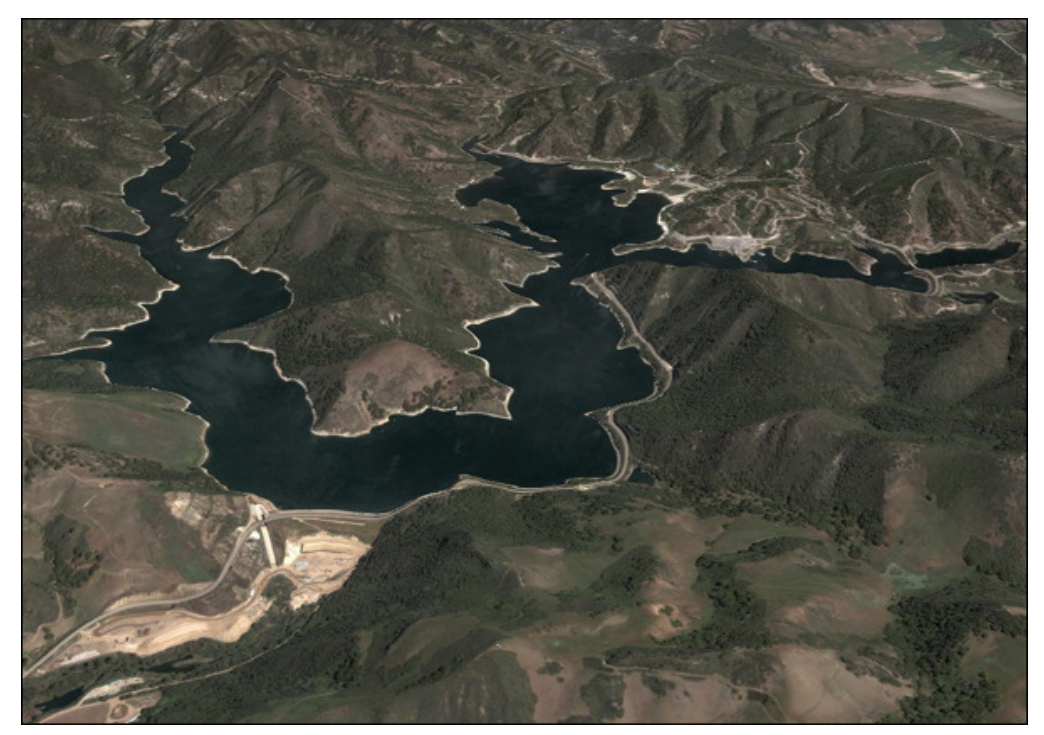

Fig 4.4 Lopez Lake, Courtesy of San Luis Obispo County Water Resources (SLOCountyWater.org) 


\section{Terminal}

Terminal Reservoir is fed from the discharge of Lopez Lake. Water remains in Terminal Reservoir for a minimum of 30 days prior to treatment at the Lopez Water Treatment Plant (Werst, et al, 2005). It is listed here separately from Lopez but is small enough not to qualify as a "major reservoir" as described by the San Luis Obispo County Hydrologic Report.

\section{Salinas}

The Salinas reservoir (also know as Santa Margarita Lake) captures water from 112 square miles of watershed and is located near Santa Margartia. Santa Margarita lake as the capacity to store 23,843 acre feet of water. The reservoir is operated by the San Luis Obispo County Flood Control and Water Conservation District and provides water to the City of San Luis Obispo.

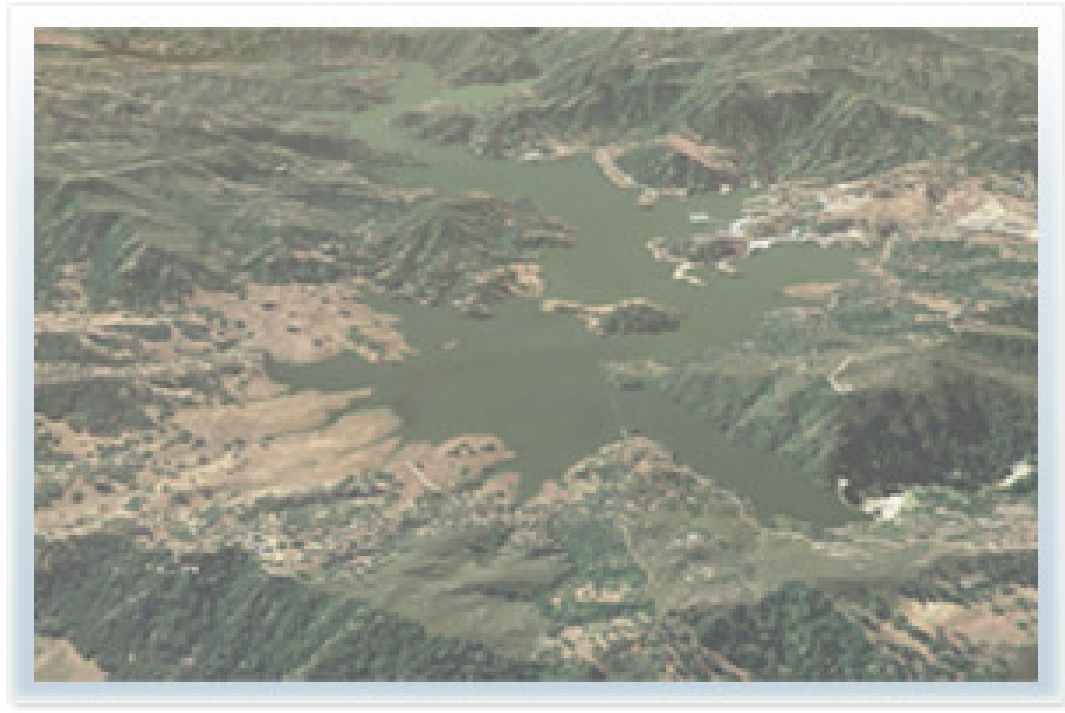

Fig 4.5 Santa Margarita (or Salinas) Reservoir, Courtesy of San Luis Obispo County Water Resources (SLOCountyWater.org) 


\section{Chorro}

Chorro Reservoir is operated by California Men's Colony and is located in the Chorro Creek Watershed (Werst, et al, 2005).

\section{Whale Rock}

Whale Rock Reservoir was constructed in 1961 and has a capacity of 40,662 acre feet. The reservoir collects water from 20.6 square miles of surface area. The owner/operator of the reservoir is the Whale Rock Commission. The reservoir provides water to the City of San Luis Obispo, Cal Poly State University and California Men's Colony (Werst, et al, 2005).

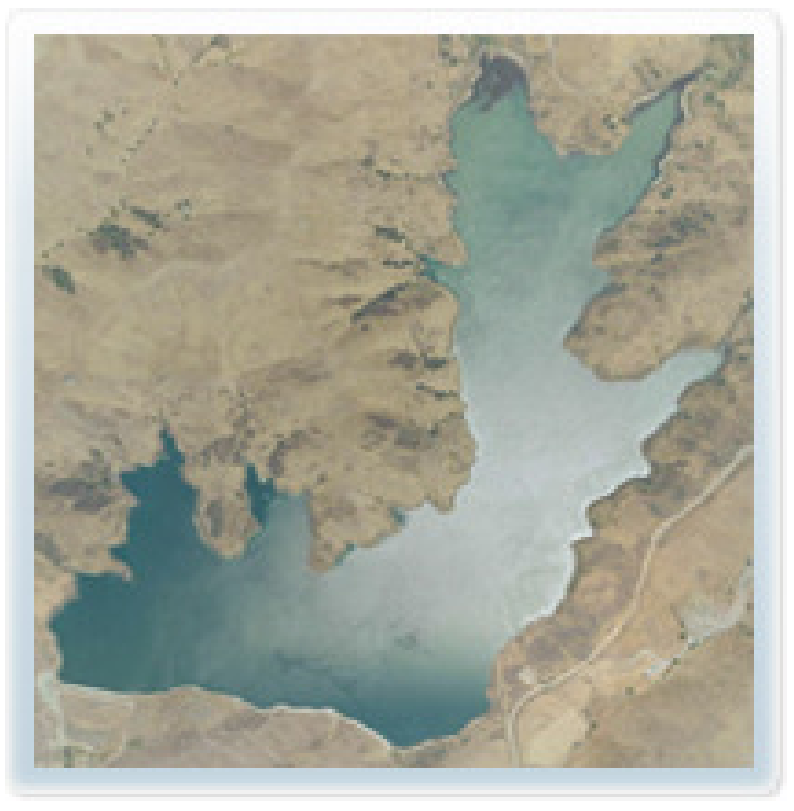

Figure 4.6 Whale Rock Reservoir, Courtesy of San Luis Obispo County Water Resources (SLOCountyWater.org) 
The owner/operator of each of the five major reservoirs is listed below. Data on water quality trends, both in the reservoir and from its tributaries should be available from the owner/operator specific to that reservoir.

Table 4.3 Reservoir Data Table

(Excerpt from San Luis Obispo Hydrologic Report (Werst, et al, 2005))

\begin{tabular}{|c|c|c|c|c|c|c|c|c|c|}
\hline $\begin{array}{c}\text { Dams and } \\
\text { Reserviors }^{1}\end{array}$ & $\begin{array}{c}\text { State } \\
\text { Dam } \\
\text { Number }^{2} \\
\end{array}$ & $\begin{array}{c}\text { Year } \\
\text { Completed }^{3}\end{array}$ & $\begin{array}{c}\text { Drainage } \\
\text { Area } \\
{\text { (sq. } \mathrm{mi})^{4}}^{4} \\
\end{array}$ & $\begin{array}{c}\text { Reservoir } \\
\text { Capacity } \\
\text { (acre-ft) }^{5}\end{array}$ & $\begin{array}{c}\text { Reservior } \\
\text { Area } \\
\text { (acres) }^{6}\end{array}$ & $\begin{array}{c}\text { Crest } \\
\text { Elevation } \\
{\text { (ft })^{7}}^{7}\end{array}$ & $\begin{array}{c}\text { Spillway } \\
\text { Elevation } \\
(\mathrm{ft})^{8} \\
\end{array}$ & Location $^{9}$ & Owner/Operator ${ }^{10}$ \\
\hline Nacimiento & $1008-000$ & 1957 & 324 & 350,000 & 5,400 & 825 & 800 & $\begin{array}{c}35^{\circ} 45.5^{\prime} \\
120^{\circ} 53.0^{\prime}\end{array}$ & \begin{tabular}{|c|} 
Monterey County Water \\
Resources Agency
\end{tabular} \\
\hline Lopez & $1055-000$ & 1969 & 70 & 52,500 & 950 & 536 & 520 & $\begin{array}{c}35^{\circ} 11.3^{\prime} \\
120^{\circ} 29.2^{\prime}\end{array}$ & $\begin{array}{l}\text { San Luis Obispo County } \\
\text { Flood Control and Water } \\
\text { Conservation District }\end{array}$ \\
\hline $\begin{array}{l}\text { Terminal } \\
\text { (Lopez) }\end{array}$ & 1055.002 & 1969 & 0.6 & 844 & 37 & 335 & 329 & $\begin{array}{l}35^{\circ} 10.2^{\prime} \\
120^{\circ} 32.0^{\prime}\end{array}$ & $\begin{array}{l}\text { San Luis Obispo County } \\
\text { Flood Control and Water } \\
\text { Conservation District }\end{array}$ \\
\hline \begin{tabular}{|l} 
Salinas \\
Dam/Santa \\
Margarita \\
Lake \\
\end{tabular} & $9000-202$ & 1942 & 111 & 23,843 & 793 & 1325 & 1301 & $\begin{array}{l}35^{\circ} 20.0^{\prime} \\
120^{\circ} 30.1^{\prime}\end{array}$ & Corps of Engineers \\
\hline Whale Rock & $1-040$ & 1960 & 20.8 & 40,662 & 594 & 233 & 216 & $\begin{array}{c}35^{\circ} 11.3^{\prime} \\
120^{\circ} 29.2^{\prime}\end{array}$ & $\begin{array}{l}\text { Whale Rock } \\
\text { Commission }\end{array}$ \\
\hline $\begin{array}{l}\text { Chorro } \\
\text { Creek }\end{array}$ & $1-072$ & 1941 & 3.2 & 90 & 10 & 595 & 580 & $\begin{array}{c}35^{\circ} 20.2^{\prime} \\
120^{\circ} 41.2^{\prime}\end{array}$ & $\begin{array}{l}\text { State Department of } \\
\text { Corrections }\end{array}$ \\
\hline
\end{tabular}

Notes:

1. All data taken from California DWR Bulletin No. 17-00 "Dams within Juristiction of the State of California."

The name of the dam is as assigned by the owner on the DWR application.

2. The Dam Number is as assigned by DWR; Salinas Dam is a federal dam.

3. The Year Completed is the date the original construction was completed.

4. The Drainage Area is the watershed tributary to the dam in square miles.

5. The Reservoir Capacity is the total storage volume in acre-feet, including dead storage.

6. The Reservoir Area is the surface area, in acres, of the reservoir at maximum water storage elevation.

7. The Crest Elevation is the elevation at the top of the dam in feet (USGS datum or approx USGS datum).

8. The Spillway Elevation was calculated from DWR data by subtracting the freeboard from the crest elevation.

9. Location is the latitude and longitude coordinates of the center point of the dam.

10. Owner/Onerator is the name of the Owner as it aboears on the DWR abolication.

The County of San Luis Obispo has established an objective for boron concentration for specific creeks and watersheds within the county. Water quality objectives are generally based on the California Code of Regulations (CCR), Title 22 requirements. In the case of boron, no standard exists in CCR, Title 22, so the standard has been established by the Regional Water Quality Control Board. 


\section{Table 4.4 Surface Water Quality Objectives, San Luis Obispo County Master Water Plan (table modified to include only boron). Water planning area defined more fully in Appendix A.}

\begin{tabular}{|l|l|}
\hline \multicolumn{2}{|c|}{ Surface Water Quality Objectives } \\
\hline Water Planning Area & Boron (mg/L) \\
\hline WPA - 1 (North coast and Santa Rosa Creek) & 0.2 \\
\hline WPA - 3 (Los Osos/Morro Bay and Chorro Creek) & 0.2 \\
\hline WPA - 4 (San Luis Obispo/Avila and San Luis Obispo Creek) & 0.2 \\
\hline WPA - 5 (Five Cities and Arroyo Grande Creek) & 0.2 \\
\hline WPA - 9a (Salinas and Salinas River) & 0.2 \\
\hline
\end{tabular}

\section{State Water Project}

State water is currently being supplied to the City of Morro Bay, the California Mens Colony, County Operations Center, Cuesta College, the City of Pismo Beach, Oceano Community Services District, San Miguelito MWC, Avila Beach Community Services District, Avila Valley MWC and San Luis Coastal Unified School District through the Polonio Pass Water Treatment Plant and pipeline system. This use is currently less than the 25,000 Acre-Feet per year allocated by the Department of Water Resources to the San Luis Obispo County Flood Control and Water Conservation District in 1963. Excess allocation Acre-Feet can be used to ensure normal delivery in years where the delivery from the State is less than $100 \%$, for groundwater banking (currently being evaluated in the Paso Robles subbasin), for sale, and for contracted use within the County (SLOCountyWater.org). 


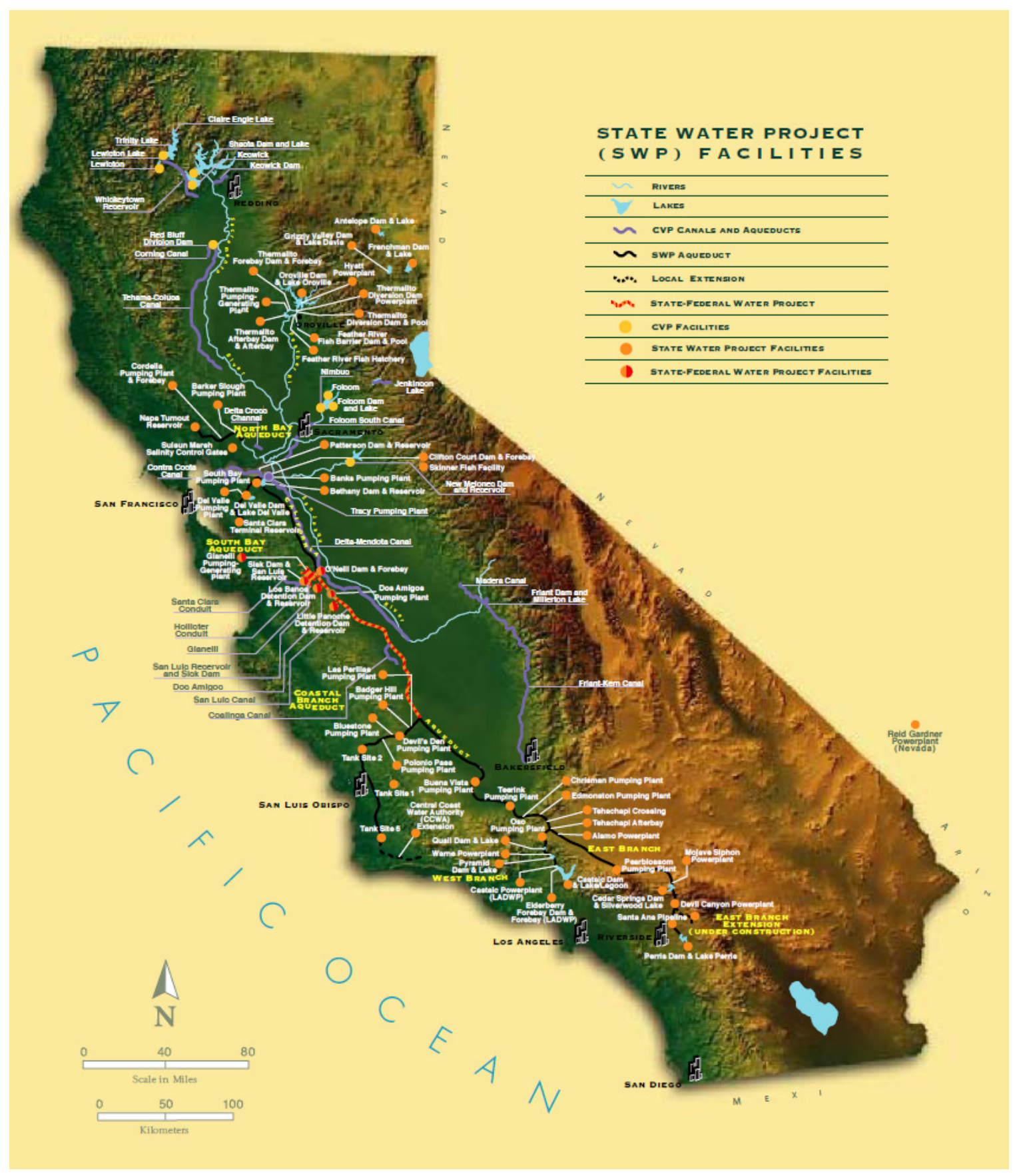

Figure 4.7 San Luis Obispo State Water Project Map, (http://www.swpao.water.ca.gov/index.cfm).

The State Water Project (SWP) delivers water to 37 million Californians and is operated and maintained as part of the California Department of Water Resources. The Operations and Maintenance Division is responsible for monitoring the chemical, 
physical and biological water quality parameters of the state water project. Grab sampling is conducted by staff from five field divisions which then are sent for analysis to Bryte Laboratory (Montoya and Smith 2007).

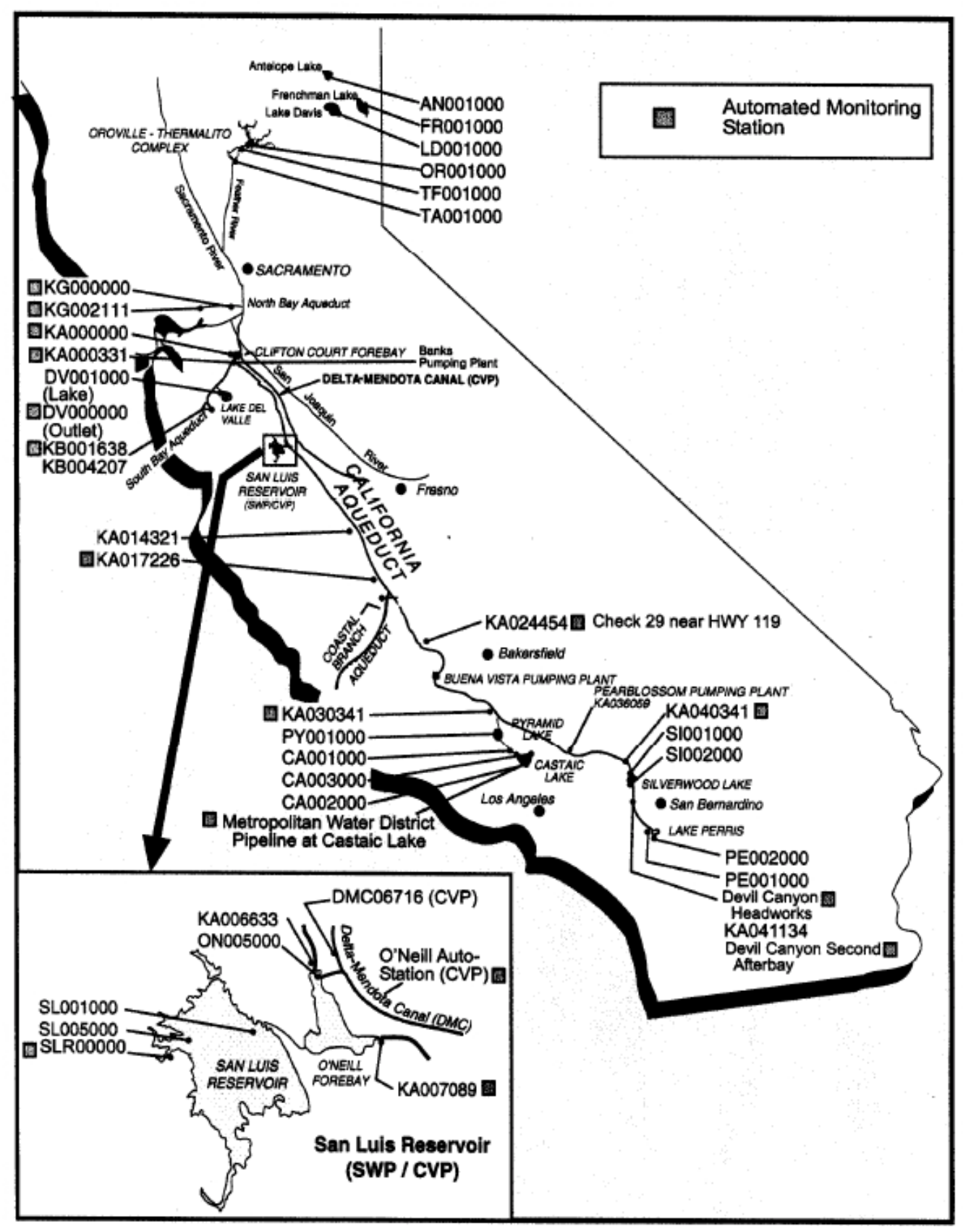

Figure 4.8 Automated Water quality monitoring stations, Sate Water Project (Montoya and Smith, 2007) 
In addition to the continuous water quality monitoring data provided by the automated stations, grab samples are taken at hand sampled locations along the SWP (http://www.swpao.water.ca.gov/index.cfm).

Table 4.5 Water Quality Grab Sample (partial data set). Provided From Monthly Grab Samples Operations and Maintenance Division, California Department of Water Resources(http://www.swpao.water.ca.gov/index.cfm).

Water Quality at Selected Grab Sample Locations May 2008

\begin{tabular}{|c|c|c|c|c|c|c|c|c|c|}
\hline \multirow[b]{2}{*}{ Constituent } & \multirow[b]{2}{*}{ Units } & \multirow[b]{2}{*}{$\begin{array}{l}\text { Detection } \\
\text { Limit }\end{array}$} & \multirow[b]{2}{*}{$\begin{array}{l}\text { Thermalito } \\
\text { Afterbay at } \\
\text { Outlet, } \\
\text { TA001000 }\end{array}$} & \multirow[b]{2}{*}{$\begin{array}{l}\text { North Bay } \\
\text { Aqueduct } \\
\text { Barker Slough } \\
\text { Pumping Plant, } \\
\text { KG000000 }\end{array}$} & \multirow[b]{2}{*}{$\begin{array}{l}\text { Delta-Mendota } \\
\text { Canal } \\
\text { Upstream } \\
\text { McCabe Road, } \\
\text { DMC06716 }\end{array}$} & \multicolumn{4}{|c|}{ California Aqueduct } \\
\hline & & & & & & $\begin{array}{l}\text { Harvey Banks } \\
\text { Delta Pumping } \\
\text { Plant, } \\
\text { KA000331 }\end{array}$ & $\begin{array}{c}\text { O'Neill Forebay } \\
\text { Outlet } \\
\text { (Check 13), } \\
\text { KA007089 }\end{array}$ & $\begin{array}{l}\text { Kettleman City } \\
\text { (Check 21), } \\
\text { KA017226 }\end{array}$ & $\begin{array}{c}\text { Near } \\
\text { Highway } 119 \\
\text { (Check 29), } \\
\text { KA024454 }\end{array}$ \\
\hline Alkalinity & $\mathrm{mg} / \mathrm{L}$ as $\mathrm{CaCO}_{3}$ & 1 & 44 & 110 & 60 & 62 & 81 & 81 & 80 \\
\hline Antimony & $\mathrm{mg} / \mathrm{L}$ & 0.001 & $<0.001$ & $<0.001$ & $<0.001$ & $<0.001$ & $<0.001$ & $<0.001$ & $<0.001$ \\
\hline Arsenic & $\mathrm{mg} / \mathrm{L}$ & 0.001 & $<0.001$ & 0.003 & 0.002 & 0.002 & 0.002 & 0.002 & 0.002 \\
\hline Beryllium & $\mathrm{mg} / \mathrm{L}$ & 0.001 & $<0.001$ & $<0.001$ & $<0.001$ & $<0.001$ & $<0.001$ & $<0.001$ & $<0.001$ \\
\hline Boron & $\mathrm{mg} / \mathrm{L}$ & 0.1 & $<0.1$ & 0.2 & 0.2 & 0.2 & 0.2 & 0.2 & 0.2 \\
\hline
\end{tabular}

Agricultural drainage, stormwater, saline groundwater inputs, and point source discharge locations have been contributing to increased salinity levels (including boron) to parts of the State Water Project since its inception (Montoya 2007). In a memo to the Environmental Assessment Branch Chief for the DWR Division of Operations and Maintenance, a staff environmental scientist writes: "Although not a major direct concern to human health, salinity can cause other problems for SWP contractors. Elevated salinity in drinking water can: 1 . be an indicator of bromide, a disinfection by-product precursor; 2. limit the use of recycled water for groundwater recharge or crop irrigation; and, 3. reduce opportunities for blending with higher-salinity sources (Montoya 2007). 


\section{WATER IMPORTS From the City OF SANTA MARIA, CALIFORNIA}

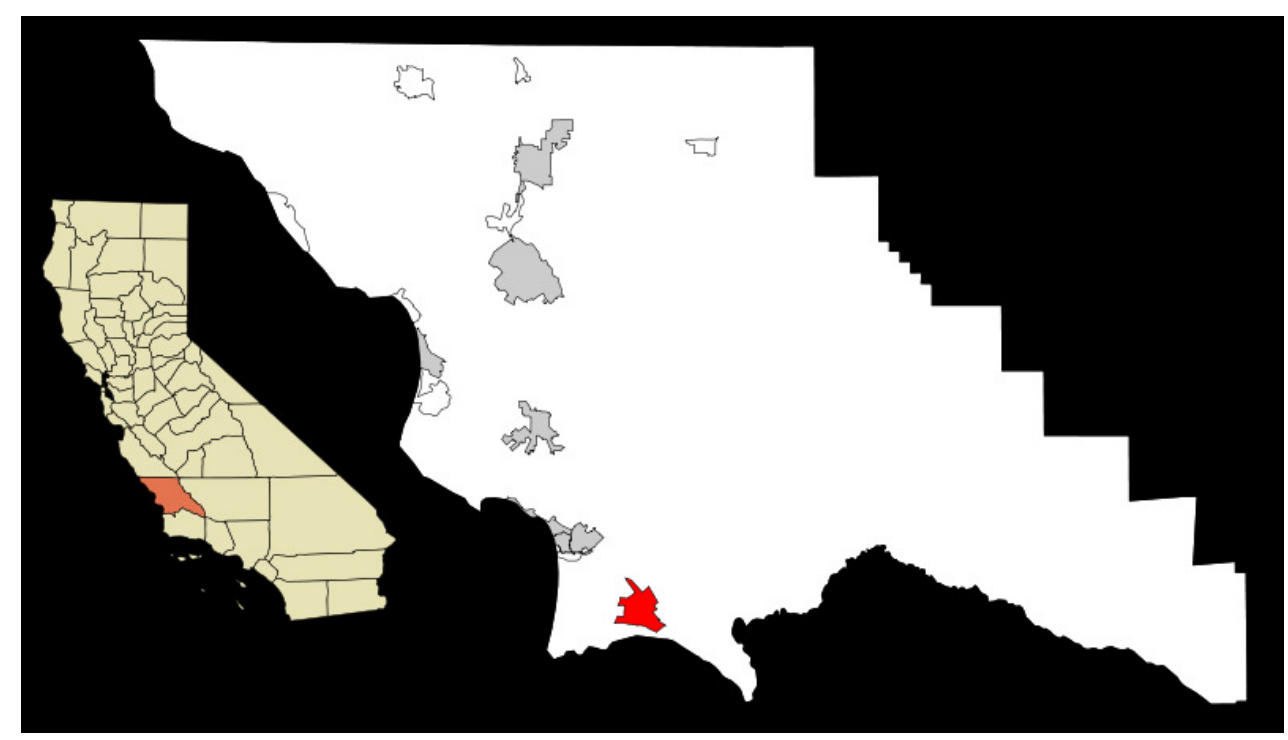

Figure 4.7 Map of San Luis Obispo County within California, Nipomo highlighted in red Provided by

http://commons.wikimedia.org/wiki/Image:San Luis Obispo County California_Incorporated and Unincorporated_areas_Nipomo_Highlighted.svg

The Nipomo Community Services District serves approximately 12,000 people with water service. In 2005 it was decided by the California State Superior Court that Nipomo would import a minimum of 2,500 acre feet of water each year to the Nipomo Mesa Management Area. This requirement has been issued as a result of a diminishing source of water and competing claims to the Santa Maria Groundwater Basin. To satisfy the settlement import requirement, the Nipomo Community Services District is planning to import water from the City of Santa Maria (Buel, et al., 2008).

The impact of this settlement requires hydraulic analysis, currently being conducted. One of the criteria being studied is the water quality of the imported water. As it pertains to this source water protection plan, this water should be evaluated for boron concentration and the possible impact to soil and water concentrations where 
applied for irrigation or as discharge from private and public wastewater facilities. The water quality evaluation completed by Boyle Aecom notes that "the Santa Maria water, being a blend of groundwater and surface water, has a significantly different water quality than the NCSD groundwater. Water quality parameters of concern include TDS, chloride, hardness and corrosivity" (Buel, et al., 2008).

\section{Crop Production}

Because of the semi-arid to arid nature of the climate in San Luis Obispo County, many of the agricultural crops require regular irrigation. Crop production is of great economic importance to county residents and county government. 


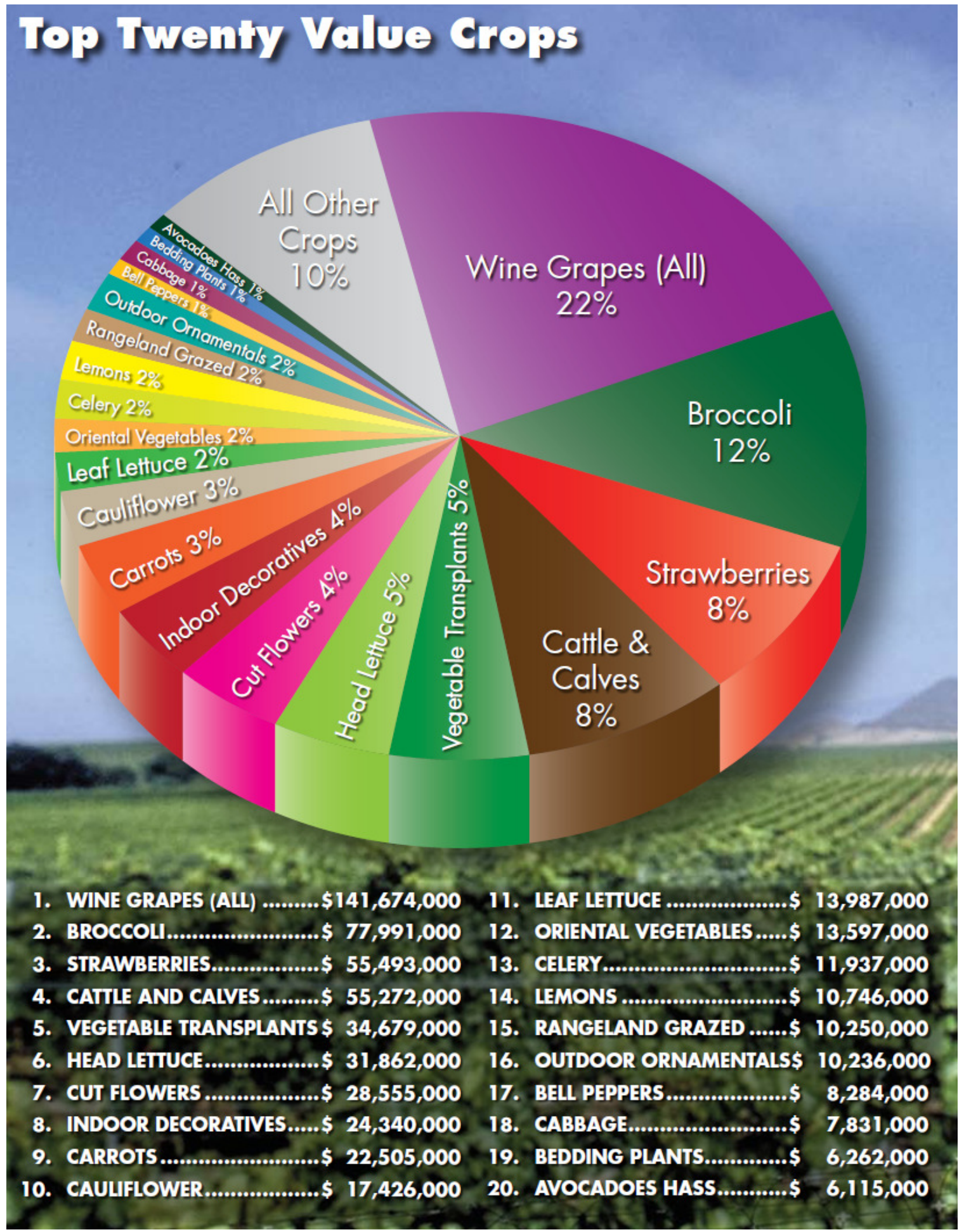

Figure 4.8 The Top Twenty Value Crops for San Luis Obispo County Agriculture, 2007 (Auchinache, Lynda, 2007 Annual Crop Report). 


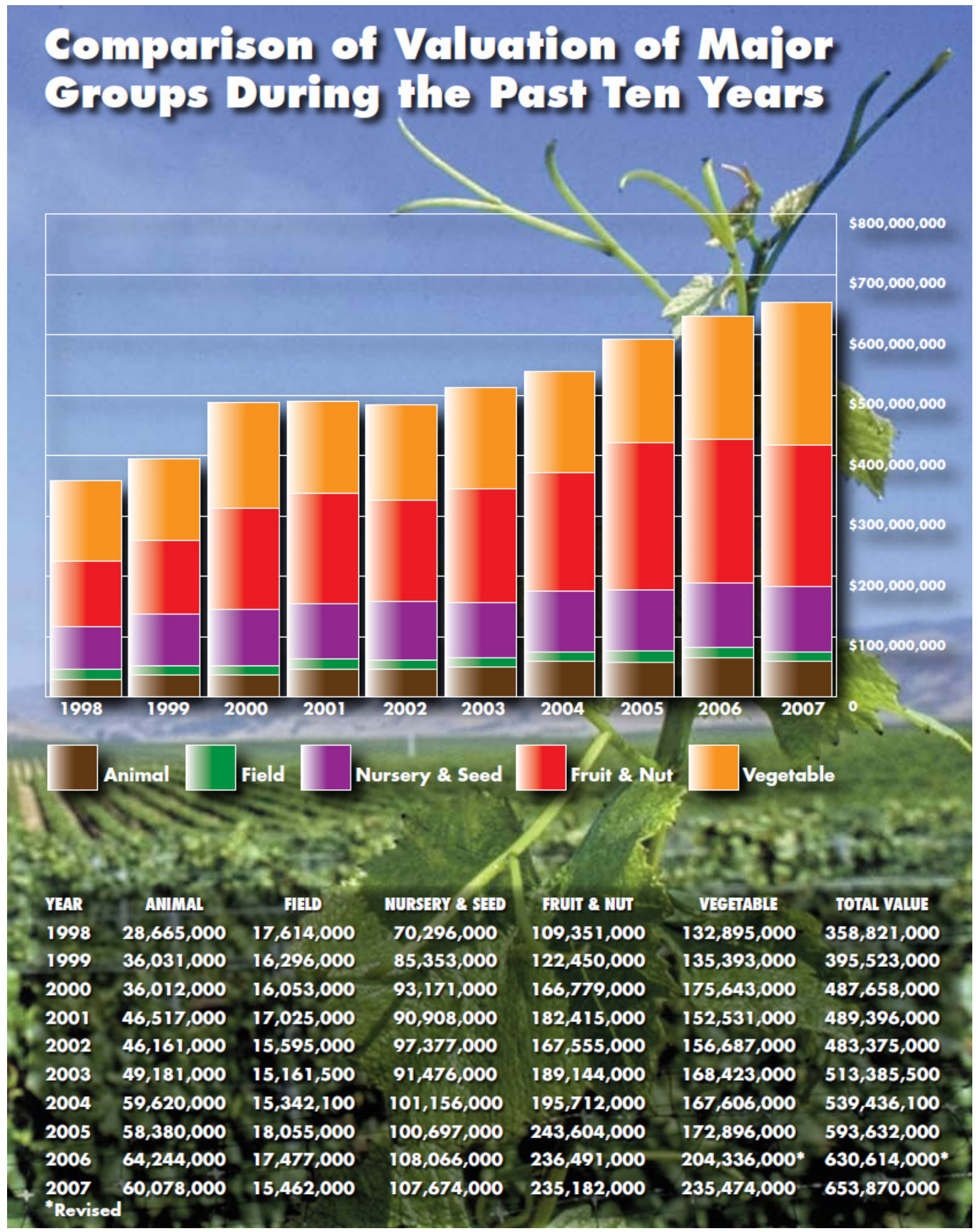

Figure 4.9 Increasing value of crops over ten year period (From Auchinache, Lynda, 2007 Annual Crop Report) 
Irrigated crop production can enhance soil salinity to levels that threaten sustainable agriculture production. As described by Fugro West and Cleath Associates in the 2002 Paso Robles Groundwater Basin Study, the physical situations and processes that can lead to excess soil salts are:

- Water used for irrigation contains salts, adding salt to soils;

- Crops use water but leave many salts behind;

- Salts will accumulate in soils if they are not removed

The salts with the best known incidence of toxicity in plants are sodium, boron, and chloride (when water is applied to leaves causing leaf burn) (Fugro West and Cleath Associates, 2002).

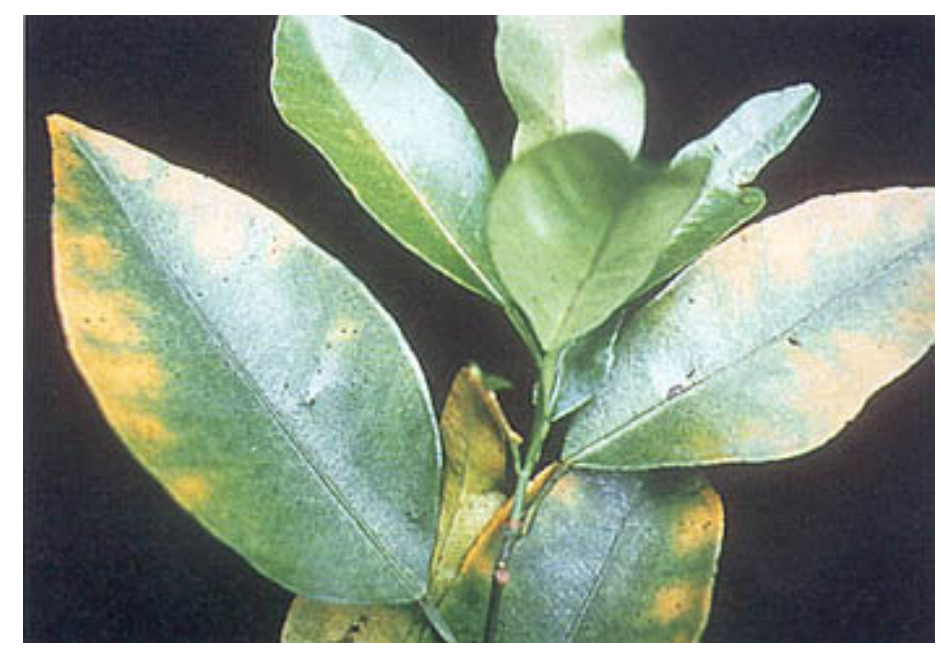

Figure 4.10 Boron Toxicity in Citrus

Picture from the Food and Fertilizer Technology Center for the Asian and Pacific Region

While boron is an essential micronutrient in plant processes, the range between toxicity and deficiency is very narrow. "Boron availability to plants depends on soil texture, clay mineralogy, organic matter, $\mathrm{pH}$, temperature and soil moisture content" (Corwin, et al., 1999). 
Table 4.6 Top 10 value crops correlated with boron toxicity data Data from 2007 Top Value Crops and 1990 U.S Salinity Laboratory data

\begin{tabular}{|c|c|c|}
\hline \multirow{2}{*}{$\begin{array}{c}\text { Top } 20 \text { Value } \\
\text { Crops for San } \\
\text { Luis Obispo } \\
\text { County (Annual } \\
\text { Crop Report, } \\
2007\end{array}$} & \multicolumn{2}{|c|}{$\begin{array}{c}\text { Boron Tolerance Limits for } \\
\text { Agricultural Crops, U.S. Salinity } \\
\text { Laboratory, } 1990\end{array}$} \\
\hline & $\begin{array}{c}\text { Binomial } \\
\text { Nomenclature }\end{array}$ & $\begin{array}{c}\text { Boron } \\
\text { Tolerance } \\
\text { ppm }\end{array}$ \\
\hline Wine Grapes & Vitis vinifera & $0.5-0.75$ \\
\hline Broccoli & $\begin{array}{c}\text { Brassica oleracea } \\
\text { botrytis }\end{array}$ & 1.0 \\
\hline Strawberries & Fragaria sp. & $0.75-1.0$ \\
\hline Cattle and Calves & N/A & N/A \\
\hline $\begin{array}{l}\text { Vegetable } \\
\text { Transplants }\end{array}$ & Will vary & Will vary \\
\hline Head Lettuce & $\begin{array}{l}\text { Lactuca sativa } \\
\text { (lettuce) }\end{array}$ & 1.3 \\
\hline Cut Flowers & Will vary & Will vary \\
\hline $\begin{array}{c}\text { Indoor } \\
\text { Decoratives }\end{array}$ & Will vary & Will vary \\
\hline Carrots & Daucus carota & $1.0-2.0$ \\
\hline Cauliflower & $\begin{array}{c}\text { B. oleracea } \\
\text { botrytis }\end{array}$ & 4.0 \\
\hline Leaf Lettuce & $\begin{array}{c}\text { Lactuca sativa } \\
\text { (lettuce) }\end{array}$ & 1.3 \\
\hline $\begin{array}{c}\text { Oriental } \\
\text { Vegetables }\end{array}$ & Will vary & Will vary \\
\hline Celery & Apium graveolens & 9.8 \\
\hline Lemons & Citrus limon & 0.5 \\
\hline Rangeland & Will vary & Will vary \\
\hline $\begin{array}{c}\text { Outdoor } \\
\text { Ornamentals }\end{array}$ & Will vary & Will vary \\
\hline Bell Peppers & $\begin{array}{c}\text { Capsicum } \\
\text { annuum (red bell } \\
\text { pepper) }\end{array}$ & $1.0-2.0$ \\
\hline Cabbage & $\begin{array}{c}\text { Brassica oleracea } \\
\text { capitata }\end{array}$ & $2.0-4.0$ \\
\hline \multicolumn{3}{|l|}{ Bedding Plants } \\
\hline $\begin{array}{l}\text { Avocadoes } \\
\text { (Hass) }\end{array}$ & Persea americana & $0.5-0.75$ \\
\hline
\end{tabular}


The following is a general summary of boron concentrations and the restriction on use for crops. In some cases, deliberately pairing crops with water and soil boron concentrations most suitable to those crops may prove to be a valuable management tool.

Table 4.7 Modified from Standards for Judging the Suitability of Water for Irrigation, Fugro West and Cleath and Associates, August 2002

\begin{tabular}{|c|c|c|c|}
\hline $\begin{array}{c}\text { Parameter } \\
\begin{array}{c}\text { Boncentration for } \\
\text { all Crops (ppm) }\end{array}\end{array}$ & None & Slight to Moderate & Severe \\
\hline$<0.5$ & -- & $\begin{array}{c}\text { Suitable for all } \\
\text { crops }\end{array}$ & -- \\
\hline $0.5-0.75$ & $\begin{array}{c}\text { Most vegetable and } \\
\text { field crops }\end{array}$ & -- & Tree and vine crops \\
\hline $0.75-1.0$ & $\begin{array}{c}\text { Many vegetable and } \\
\text { field crops }\end{array}$ & $\begin{array}{c}\text { Sweet potato, } \\
\text { wheat, bean, } \\
\text { strawberry, } \\
\text { artichoke }\end{array}$ & Tree and vines \\
\hline $1.0-2.0$ & $\begin{array}{c}\text { Tomato, alfalfa, } \\
\text { sugar beets, and } \\
\text { celery }\end{array}$ & $\begin{array}{c}\text { Most vegetable and } \\
\text { field crops }\end{array}$ & $\begin{array}{c}\text { Trees and vines, } \\
\text { many field and } \\
\text { vegetable crops }\end{array}$ \\
\hline $2.0-6.0$ & $\begin{array}{c}\text { Sorghum, cotton, } \\
\text { and asparagus }\end{array}$ & $\begin{array}{c}\text { Tomato, alfalfa, } \\
\text { sugar beet and vetch }\end{array}$ & Most other crops \\
\hline
\end{tabular}

\section{IDENTIFYING ANTHROPOGENIC SOURCES OF BORON}

The task for identifying anthropogenic sources of boron should be divided into nonpoint and point sources of boron contamination. Point sources are pollution sources that come directly from an identifiable source. Point sources of pollution may include landfills, discharge from wastewater treatment plants, mining operations, dairies, etc. Non-point sources of pollution are usually more difficult to identify. Point sources of boron contamination may include pubic wastewater treatment plant discharge and discharge from manufacturing plants. 
Non-point sources of pollution are typically described as sources that occur over a large area, where one specific source is not identifiable. Non-point sources of pollution of boron may include runoff, septic systems, agricultural practices such as fertilizer, herbicide or pesticide application, and road construction activities.

The San Luis Obispo County Planning Department has access to land use type and permitting information. The Central Coast Regional Water Quality Control Board regulates point source discharge. The Agricultural / Weights and Measures Department of San Luis Obispo County, the Natural Resources Conservation Service and the Resource Conservation Districts have agricultural land use data and educational symposiums to assist identifying non-point sources of pollution.

\section{WATER QuAlity Data}

Water quality data exists in archived digital and hard copy files throughout many state and county agencies. The lead agency request for data from these agencies will include the following: source of water, date of sample, depth of sample taken (where applicable), method of boron detection, reporting laboratory, depth of well (where applicable), depth to water (where applicable), boron concentration. The data collected will be included in the source water protection plan if the sample analysis was performed by a state approved laboratory.

This data will be used to produce graphs of water quality data containing the parameters surveyed for each of the twenty-two groundwater basins and the surface water reservoirs serving San Luis Obispo County. When locations have been sampled more 
than once, trends will also be mapped to show any historical change in boron

concentration. An illustration of the mapping technique can be referenced in appendix .

Table 4.8 Water Quality Data Archives

\begin{tabular}{|l|l|}
\hline Data Source & Data Archived \\
\hline $\begin{array}{l}\text { Department of Water } \\
\text { Resources }\end{array}$ & $\begin{array}{l}\text { Location and some water quality data on all water wells } \\
\text { permitted for construction and destruction in San Luis } \\
\text { Obispo County }\end{array}$ \\
\hline USGS & $\begin{array}{l}\text { Groundwater Ambient Monitoring and Assessment } \\
\text { (GAMA): a statewide project to characterize groundwater } \\
\text { constituents and trends }\end{array}$ \\
\hline $\begin{array}{l}\text { San Luis Obispo County } \\
\text { Servironmental Health }\end{array}$ & $\begin{array}{l}\text { Boron concentration for all small public water systems } \\
\text { within San Luis Obispo County are housed }\end{array}$ \\
\hline $\begin{array}{l}\text { Central Coast Regional } \\
\text { Water Quality Control } \\
\text { Board }\end{array}$ & $\begin{array}{l}\text { Central Coast Ambient Monitoring Program (CCAMP): } \\
\text { Water quality monitoring and assessment program }\end{array}$ \\
\hline $\begin{array}{l}\text { California Department } \\
\text { of Health Services }\end{array}$ & $\begin{array}{l}\text { GeoTracker database: an environmental databse for } \\
\text { regulated facilities in California }\end{array}$ \\
\hline $\begin{array}{l}\text { U.S. Environmental } \\
\text { Protection Agency }\end{array}$ & $\begin{array}{l}\text { STORET database and Legacy Data Center: a repository } \\
\text { for water quality, biological, and physical data }\end{array}$ \\
\hline $\begin{array}{l}\text { USGS } \\
\text { Interferometric Synthetic Aperture Radar (InSAR): } \\
\text { displacement maps are used with groundwater level data } \\
\text { to help identify large basins and smaller subbasins }\end{array}$ \\
\hline
\end{tabular}

\section{MANAGEMENT STRATEGIES}

The San Luis Obispo County Master Water Plan, overseen by San Luis Obispo County Public Works and the San Luis Obispo Water Resources Advisory Committee (WRAC) states that the County's goal for long term usability and reliability of water resources is water quality (EDAW Inc. 2001). The Master Water Plan states "The quality of a water supply, whether its end beneficial use is municipal, agricultural, or environmental, will dictate if and how that water is used". Given this dictate, the data on boron concentration in soils, groundwater and surface water should be addressed in planning decisions for how boron contamination can be prevented. 
One of the most important strategies in the development of a source water protection plan is the partnership between entities to protect the integrity of the soil and water system. The design of this source protection plan will be to ensure that there is an understanding of the cross jurisdictional nature of not only the data currently available on boron levels in water, but also the multi-agency means by which boron can be monitored and by which protection measures can and should be instituted. After the lead agency has gathered and correlated the data available on boron concentration in the various groundwater basins, surface water sources, and those sources of water from outside of the county, and shared that data with the interested parties, decisions can be made on how best to manage these sources.

Possible outcomes may be:

- Effluent treatment for boron;

- Crop rotation, a change in fertilizer, insecticide or herbicide applications;

- More stringent requirements on water well construction to prevent the mixing of aquifers with different water quality;

- A change in the destination of state water project water banking;

- Public education and outreach campaigns;

- A routine monitoring system;

- Leaching where applicable;

- Treatment to water from hydrothermal springs;

- And other management options. 


\section{CONCLUSION}

The goal of any source water protection program is to prevent the pollution of water sources. Generally the four basic steps are to 1) delineate the source water protection areas; 2) identify sources of contamination that may affect the source water protection areas; 3) identify management strategies for these sources and 4) long term planning (Ainsworth et al. 1996). With the approach outlined in the design of this source water protection plan these four steps can be achieved. The source water protection areas have been identified as the twenty two groundwater basins within San Luis Obispo County, responsible for supplying more of the county's water needs than any other source, and the five major surface water bodies in the county. The sources of contamination include the natural and anthropogenic sources mentioned earlier in this report, and can be correlated with the concentrations measured at the sampled sources after data capture is complete. The management strategies will require the coordination of all parties with a vested interest in quality, partially summarized in table 4.1. Long term planning will require a continued cooperation between vested parties and a collaborative approach during decision making of the possible outcomes for high levels of boron in discharge, groundwater, surface water, or water supplied from out of County. 


\section{REFERENCES}

Ainsworth, Steve, H. Brown, and P. John. 1996. How's the water? Public Management 78:15-20.

Auchinache, Lynda. 2007. 2007 Annual Crop Report. San Luis Obispo County Department of Agriculture Weights and Measures. San Luis Obispo, California.

Ayers, R.S. and D.W. Westcot. Water Quality for Agriculture. 1989, 1994. FAO Irrigation and Drainage. Paper 29 Rev. 1.

Banuelos, G.S., G. Cardon, B. Mackey, J. Ben-Asher, L. Wu, P. Beuselinck, S. Akohoue, and S. Zambrzuski. 1993. Boron and selenium in boron-laden soils by four sprinkler irrigated plant species. Journal of Environmental Quality 22: 786-792.

Barranco, Wade T., P.F. Hudak, and C.D. Eckhert. 2007. Evaluation of ecological and in vitro effects of boron on prostate cancer risk. Cancer Causes and Control 18:71-77.

Buel, Bruce, M. Nunley, J. Reynolds, C.Romero, M. McEwen, E. Shields, and A. Romer. 2008. Nipomo Waterline Intertie Project Preliminary Engineering Memorandum. Boyle Aecom, San Luis Obispo, California.

California Department of Health Services. 2000. Drinking water source assessment and protection (DWSAP) program: minimum components of a drinking water source assessment. Department of Health Services, Sacramento.

California Department of Water Resources. [Online.] Available at http://www.water.ca.gov/swp/ (Verified 11 March 2010).

Corwin, Dennis L., S. Godberg, and A. David. 1999. Evaluation of a Functional Model for Simulating Boron Transport in Soil. Soil Science 164, 10: 697-717.

Drinking Water Program (DWP), California Department of Public Health. [Online.] Available at http://www.cdph.ca.gov/certlic/drinkingwater/Pages/default.aspx (Verified 06 March 2010).

EDAW Inc. 2001. San Luis Obispo County Master Water Plan. San Luis Obispo County Public Works, CA.

Food and Fertilizer Technology Center for the Asian and Pacific Region. [Online.] Available at http://www.agnet.org/library/nc/128a/ (Verified 06 March 2010).

Fugro West and Cleath and Associates. 2002. Paso Robles groundwater basin study. San Luis Obispo County Public Works. 
Glueckstern, P. and M. Priel. 2007. Boron removal in brackish water desalination systems. Desalination. 205: 178-284.

Gunes, Aydin, Mehmet Alpastan, Ali Inal, M. Sait Adak, Figen Eraslan, and Nuray Cicek. 2003. Effects of boron fertilization on the yield and some components of bread and durum wheat. Turkish Journal of Agriculture and Forestry 27: 329-335.

Gupta, Umesh C. 1993. Boron and its role in crop production. CRC Press, London.

Itakura, Takeshi, R. Sasai, and H. Itoh. 2005. Precipitation recovery of boron from wastewater by hydrothermal mineralization. Water Research 39:2543-2548.

Johnson, Judi. 2001. Boron: what is it and why should you care? University of California Agriculture and Natural Resources, Cooperative Extension, Yolo County.

Koc, Cengiz. 2007. Effects on environment and agriculture of geothermal wastewater and boron pollution in Great Menderes Basin. Environmental Monitoring and Assessment 125:377-388.

Kot, F.S. 2007. Boron speciation in soils irrigated with fresh and effluent municipal waters. Bulletin of Environmental Contamination and Toxicology 79:259-263.

Montoya, Barry L. 2007. Sources of Salinity in the South Sacramento-San Joaquin Delta, Memo Report, May 2007. California Department of Water Resources, Division of Operations and Maintenance, Environmental Assessment Branch.

Montoya, Barry L. and T.P. Smith. 2007 Water Quality in the State Water Project, 2002 and 2003. California Department of Water Resources, Division of Operations and Maintenance, Environmental Assessment Branch

National Climatic Data Center, United States Department of Commerce. [Online.] Available at. http://www.ncdc.noaa.gov/oa/ncdc.html (Verified 06 March 2010).

Natural Resources Conservation Service, United States Department of Agriculture. [Online.] Available at. http://www.nrcs.usda.gov/ (Verified 06 March 2010).

Nsouli, B., T. Darwish, K. Sahraman, A. Bejjani, M. Roumie, and J.P. Thomas. 2006. Total boron assessment in soil samples from dry Mediterranean region using the thick target-particle induced gamma-ray emission technique. Nuclear Instruments and Methods in Physics Research B 249:566-570.

Peryea, Frank J. and F. T. Bingham. 1984. Reclamation and regeneration of boron in high boron soils. California agriculture - California Agricultural Experiment Station 38: 35 . 
Plaistow Source Water Protection Committee. 2001. Source water protection plan for public drinking water sources in Plaistow, New Hampshire. Source Water Protection Plan. Office, Plaistow, New Jersey.

Rainey, Charlene J., L. A. Nyquist, R. E. Christensen, P. L. Strong, B. D. Culver, and J. R. Coughlin. 1999. Daily boron intake from the American diet. Journal of the American Dietetic Association 99: 335-340.

Reid, Rob. 2007. Identification of boron tranporter genes likely to be responsible for tolerance to boron toxicity in wheat and barley. Plant Cell Physiology 48 (12):16731678.

Rowe, Gary. 1999. Surveying boron and naturally soft groundwater with a computer database. Environmental Health December: 14-19.

San Luis Obispo County. 2001. San Luis Obispo County water plan: inventory of existing supplies. [Online.] Available at http://www.slocountywater.org/mvp/pdf_files/InvExistingSupplies.pdf. (Verified 06 March 2010).

San Luis Obispo County Department of Agriculture / Weights and Measures. [Online.] Available at http://www.slocounty.ca.gov/agcomm (Verified 06 March 2010).

San Luis Obispo County Flood Control and Water Conservation District. 2005. Urban Water Management Plan 2005 Update for Flood Zone 3. San Luis Obispo County, California.

San Luis Obispo County Water Resources, Division of Public Works. [Online.] Available at http://www.slocountywater.org/site/index.htm (Verified 06 March 2010).).

Seul Bi Lee, Y.B. Lee, C.H. Lee, C.O. Hong, P.J. Kim and C. Yu. 2008. Characteristics of boron accumulation by fly ash application in paddy soil. Bioresource Technology 99:928-5932.

State Water Resources Control Board Groundwater Ambient Monitoring and Assessment Program (GAMA). [Online.] Available at http://www.swrcb.ca.gov/gama (Verified 06 March 2010).

Tisdale, Samuel L., W. L. Nelson, J. D. Beaton, and J. L. Havlin. 1993. Soil fertility and fertilizers. $5^{\text {th }}$ ed. Macmillan Publishing Company, New York.

United States Department of Agriculture, Agriculture Research Service, U. S. Salinity Laboratory. [Online.] Available at http://www.ars.usda.gov/Services/docs.htm?docid=8908 (Verified 06 March 2010). 
United States Environmental Protection Agency. [Online.] Available at. http://www.epa.gov/ (Verified 06 March 2010).

United States Geological Survey. 1998. Periodic table-boron. [Online.] Available at http://www.rcamnl.wr.usgs.gov/isoig/period/b_iig.html. (Verified 06 March 2010).

United States Geological Survey. Groundwater Ambient Monitoring Program (GAMA). [Online.] Available at http://ca.water.usgs.gov/gama/ (Verified 06 March 2010).

United States Geological Survey. 2003. Mineral commodity summaries: boron. USGS.

Werst, Jeff, K. Arnold, and F. Honeycutt. 2005. San Luis Obispo County Public Works Department, Water Years 2001-2002 and 2002-2003 Hydrologic Report. San Luis Obispo County Utilities Division, Public Works Department, California.

Yermiyahu, U., A. Ben-Gal, R. Keren, and R.J. Reid. 2008. Combined effect of salinity and excess boron on plant growth and yield. Plant and Soil 304:73-87.

Yermiyahu, U., R. Keren, and Y. Chen. 2001. Effect of composted organic matter on boron uptake by plants. Soil Science Society of America Journal 65: 1436-1441. 
APPENDiX A

Water Planning Areas (WPA), as defined by the San Luis Obispo County Master Water Plan, represent the geographic organization of the demand for water within the County. These WPA are not defined by groundwater basin or watershed boundaries (EDAW 2001).

The following is an excerpt from the San Luis Obispo County Master Water Plan

\section{Coastal Water Planning Areas 1 Through 6}

1. North Coast - Encompasses San Simeon and Cambria. Follows watershed boundary along the Santa Lucia Range to the northeast and the watershed divide between Villa Creek and Cayucos Creek to the south.

2. Cayucos - Includes coastal watersheds from Cayucos Creek to Toro Creek.

3. Los Osos/Morro Bay - Encompasses Morro Bay and those portions of Los Osos that are within the Chorro Creek watershed. Extends along Highway 1 (Cuesta College, Camp SLO, Dairy Creek Golf Course, and CMC).

4. San Luis Obispo/Avila - Includes San Luis Obispo Creek watershed as well as from Avila Beach to Montana De Oro State Park. Extends into Edna Valley up to the Pismo Creek watershed divide.

5. Five Cities - Includes Five Cities area from Pismo Creek to Arroyo Grande Creek watersheds. Encompasses Lopez Lake watershed. 6. Nipomo Mesa - Includes that portion of San Luis Obispo County that lies within the Santa Maria River watershed.

\section{Inland Water Planning Areas 7 Through 10}

7. Cuyama - Encompasses that portion of San Luis Obispo County that lies within the Cuyama River watershed (i.e. Twitchell Reservoir).

8. California Valley - Consists of the Carrizo Plain area of the County.

9a. Salinas - Generally consists of the Salinas River watershed along the Highway 101 corridor from Santa Margarita Lake north to San Miguel.

9b. Creston - Encompasses that portion of the Paso Robles ground water basin that alsocoincides with the Huerhuero Creek watershed. The northwestern boundary is generally the boundary between urban land uses of Paso Robles and the agricultural uses surrounding Creston. The southern boundary follows the watershed boundary of the Huerhuero Creek. 
9c. Shandon - Encompasses the watershed bounded by the La Panza Range to the southwest and including the Estrella Creek watershed to the north.

10. Nacimiento - Consists of that portion of the County that drains into Lake Nacimiento. 


\section{Appendix B}

\section{Sources of Archived And Current Water and SoIl Quality Data SAN Luis Obispo COUNTY}

Coastal San Luis RCD

545 Main Street Suite B-1

Morro Bay, CA 93442

(805) 772-4391

Department of Water Resources

1416 9th Street

Sacramento, CA 95814

(916) 653-5791

Mailing Address:

P.O. Box 942836

Sacramento, CA 94236

Natural Resources Conservation Service

United States Department of Agriculture

Templeton Service Center

65 S Main Street Suite 106

Templeton, CA 93465

(805) 434-0396

Regional Water Quality Control Board

Central Coast Region

895 Aerovista Place Suite 100

San Luis Obispo, CA 93401

(805) 549-3147

San Luis Obispo County Agricultural Commissioners Office

2156 Sierra Way

San Luis Obispo, CA 93401

(805) 781-5910

San Luis Obispo County Environmental Health Services

2156 Sierra Way

San Luis Obispo

(805) 781-5544 
San Luis Obispo County Flood Control and Water Conservation District

San Luis Obispo County Public Works

Water Resources Division

County Government Center

San Luis Obispo, CA 93408

(805) 781-5252

San Luis Obispo County Geologist (contracted)

Lou Rosenberg (505) 384-1010

Brain Papurello (831) 443-6970

San Luis Obispo County Planning Department

Environmental - Natural Resource Management

County Government Center

Room 200

San Luis Obispo, CA 93408

(805) 781-5010

San Luis Obispo County Public Works

Utility Division

County Government Center

San Luis Obispo, CA 93408

(805) 781-5252

San Luis Obispo County Public Works

Water Resources Division

County Government Center

San Luis Obispo, CA 93408

(805) 781-5252

San Luis Obispo County Water Resources Advisory Committee

Public Works, Water Resources Division

County Government Center

San Luis Obispo, CA 93408

(805) 781-5252

State of California, Department of Public Health

Drinking Water Programs, District 6

1180 Eugenia Place, Suite 200

Carpinteria, CA 93013

(805) 566-1326

United States Department of Agriculture

$65 \mathrm{~S}$ Main Street

Templeton, $\mathrm{Ca}$

(805) 434-0396 
United States Department of Commerce

National Climatic Data Center

Federal Building

151 Patton Avenue

Asheville, NC 28801-5001

(828) 271-4800

FAX: (828) 271-4876

University of California

Cooperative Extension San Luis Obispo County

2156 Sierra Way Suite C

San Luis Obispo, CA 93401

(805) 781-5940

Upper Salinas RCD

65 Main Street Suite 107

Templeton, CA 93465

(805) 434-0396 x4 